This is an electronic reprint of the original article. This reprint may differ from the original in pagination and typographic detail.

Author(s): Busk, Henna

Title: Sanctions and the exit from unemployment in two different benefit schemes

Year: $\quad 2016$

Version:

Please cite the original version:

Busk, H. (2016). Sanctions and the exit from unemployment in two different benefit schemes. Labour Economics, 42, 159-176.

https://doi.org/10.1016/j.labeco.2016.09.001

All material supplied via JYX is protected by copyright and other intellectual property rights, and duplication or sale of all or part of any of the repository collections is not permitted, except that material may be duplicated by you for your research use or educational purposes in electronic or print form. You must obtain permission for any other use. Electronic or print copies may not be offered, whether for sale or otherwise to anyone who is not an authorised user. 


\section{Accepted Manuscript}

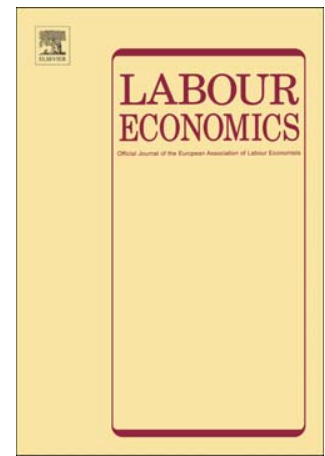

PII:

S0927-5371(16)30099-9

DOI:

doi: 10.1016/j.labeco.2016.09.001

Reference: $\quad$ LABECO 1493

To appear in: $\quad$ Labour Economics

Received date: 11 June 2013

Revised date: $\quad 29$ April 2016

Accepted date: $\quad 8$ September 2016

Please cite this article as: Busk, Henna, Sanctions and the exit from unemployment in two different benefit schemes, Labour Economics (2016), doi: 10.1016/j.labeco.2016.09.001

This is a PDF file of an unedited manuscript that has been accepted for publication. As a service to our customers we are providing this early version of the manuscript. The manuscript will undergo copyediting, typesetting, and review of the resulting proof before it is published in its final form. Please note that during the production process errors may be discovered which could affect the content, and all legal disclaimers that apply to the journal pertain. 


\title{
Sanctions and the Exit from Unemployment in Two Different Benefit Schemes
}

Henna Busk

Eerikinkatu 28A, Helsinki, fi

\begin{abstract}
This paper investigates the effect of benefit sanctions on the exit rate from unemployment using a unique set of rich register data on unemployed Finnish individuals. The timing-of-events approach is applied to distinguish between the selection and causal effects of sanctioning. The results imply that the effect of sanctions differs according to the benefits received. Sanctions encourage unemployed individuals receiving flat-rate labour market support (LMS) to find jobs, whereas unemployed individuals receiving earnings-related (UI) allowances to leave the labour force. The encouraging effect of sanctions on active labour market policy programmes is relatively small and statistically significant only among LMS recipients.
\end{abstract}

Keywords: unemployment; benefits; sanctions

JEL-classification: C41; J64; J65 


\section{Introduction}

There is a wide range of literature relating to unemployment duration and benefits (e.g., Meyer, 1990; Ham and Rea, 1987; Moffitt and Nicholson, 1982). Nonetheless, little is known about the effect of benefit sanctions. A small body of empirical literature indicates that even moderate benefit sanctions increase the job-finding rates of the unemployed (e.g., Abbring et al., 2005; Lalive et al., 2005; Van den Berg et al., 2004). Recent studies also suggest that the effect of sanctions decreases over their elapsed duration and that the effects differ for various types of unemployed individuals (Svarer 2011). For example, male immigrants are more sensitive to sanctions than male natives. Few previous studies have examined the ex ante effects of sanctions, in which the mere threat of sanctions is assumed to affect the job search efforts of the unemployed. The results in this field of study are inconclusive. Both Lalive et al. (2005) and Boone et al. (2009) find that the ex ante effect is significant because it stimulates the outflow from unemployment. Conversely, Van den Berg and Vikström (2014) find that the ex ante effect does not have a strong influence on the re-employment rate.

This paper investigates the effect of sanctions on the exit rate from unemployment. Sanctions, which are temporary benefit exclusions, are imposed on the unemployed when suitable job offers or active labour market policy (ALMP) programmes are rejected and when job search efforts are deemed inappropriate. We use large register data from the 2003-2009 period to perform a separate analysis for earnings-related (UI) and flat-rate labour market support (LMS) benefit recipients. This study represents the first attempt to conduct such an analysis. We also perform a diverse set of sensitivity analyses. We examine the strictness of sanctions, whether sanctions influence the exit rate from unemployment to work and whether the influence of sanctions varies over time. To determine whether some individuals react to sanctions more strongly than others, we allow sanctions to interact with the characteristics of the unemployed. 
The contribution of this paper is to provide new evidence to the sparse existing literature on benefit sanctions. Most previous studies have examined the effect of sanctions on unemployment duration for individuals receiving unemployment insurance benefits. An exception is the work of Van den Berg et al. (2004), who analyse the effect of sanctions on the transition from welfare (social assistance) to work. Our study is the first to provide a comparison of two different benefit schemes. It is important to investigate the effect of sanctions for different types of benefits because individuals receiving UI benefits differ from individuals receiving LMS benefits in terms of their employment opportunities and background, and because UI benefits exceed flat-rate LMS. Compared to LMS, UI recipients should have a larger incentive to reduce the reservation wage and increase the search intensity after imposition of a sanction due to the larger reduction in the value of being unemployed.

The data set that we use is large and diverse, whereas most previous studies have used relatively small samples that were often restricted to small geographic areas (see, e.g., Van den Berg et al., 2004; Lalive et al., 2005). In this paper, we also analyse the effect of sanctions on the exit rate from unemployment to ALMP programmes and outside the labour force. Recently, number of papers report that sanctions increase not only the exit rate from unemployment to work but also the exit to non-employment (Arni et al., 2012; Røed and Westlie, 2012; Hillmann and Hohenleitner, 2012).

The remainder of this paper is organised as follows. In Section 2, we present a brief introduction to the Finnish unemployment benefit system and sanctions. The theoretical framework and econometric methods that are used in this study are discussed in Section 3. Section 4 describes the data that are used. The empirical findings of this study are presented in Section 5, and Section 6 concludes the paper. 


\section{Unemployment benefits and sanctions in Finland}

In this section, the structure of the Finnish unemployment benefit system and sanctions is introduced. This description highlights the aspects of the system that are relevant to our study. The information given applies to the period from 2003 to 2009, which is the observation period in our study.

There were no significant changes to the benefit system between the years 2003 and 2009. However, one change was made to the sanction system during the observation period. In a policy reform in 2006 the monitoring and sanctions of long-term unemployed were tightened in Finland. ${ }^{1}$ The main purpose of the reform was to activate long-term unemployed, that is, individuals who had been on flat-rate LMS for over 500 days or on UI allowance for the maximum 500 days and on LMS for over 180 days thereafter. For these individuals, ALMP measures were offered more frequently. Refusal of ALMP measures and/or work offers as well as neglecting job search plan implied exclusion of unemployment benefits until five months of work, education or ALMP measures was performed.

\subsection{Unemployment benefits in Finland}

There are two types of unemployment benefits: an UI allowance and a LMS. ${ }^{2}$ Eligibility for UI benefits requires membership in an unemployment insurance fund (either an independent fund or a fund that is specific to a trade union) and an employment history of at least 10 months during the last 28 months prior to unemployment ("the employment condition'). Both membership in a union and membership in an unemployment insurance

\footnotetext{
${ }^{1}$ The reform is available in Finnish at <http://www.finlex.fi/fi/laki/alkup/2002/20051217> (accessed 15 March 2016).

2 A third unemployment benefit, basic allowance (UA), is granted to unemployed individuals who do not belong to an insurance fund but who fulfil the employment condition. The UA is paid by the KELA for 500 days, and the level equals the LMS. UA recipients (7\% of the unemployed) were not included in this analysis because they are few in number.
} 
fund are voluntary. The maximum duration of UI is 500 business days, i.e., approximately two years. ${ }^{3}$ If a person does not fulfil the employment condition or is unemployed for more than 500 days, then he is entitled to LMS paid by the Social Insurance Institution (Kansaneläkelaitos KELA). The LMS is always means tested but the duration is essentially unlimited.

The UI benefit is based on prior earnings of the unemployed and varies between $45 \%$ and $90 \%$ of the previous income level. By contrast, the LMS is paid at a flat daily rate that was $25.63 €(551 € /$ month $)$ in 2009 . During the same year, the average daily UI allowance was $55.20 €(1,187 € /$ month $)$. The LMS is means-tested whereas the UI benefit is not, which means that the spouse's income affects the eligibility for the LMS but not for the UI benefits. Table 1 summarises the information on unemployment benefits.

Unemployed individuals who receive a sanction may apply for other benefits such as basic social assistance (SA) and/or general housing allowance (HA), although the SA can be reduced by $20 \%$ or $40 \%$ depending on the sanction ( $40 \%$ for repeated violations). ${ }^{4}$ Because the SA is means tested, the reduction is not always used (the decision is made by a caseworker). Individuals can receive unemployment benefits and SA/HA simultaneously if their incomes are sufficiently low.

\footnotetext{
${ }^{3}$ Older unemployed individuals (those over 55) who receive UI allowances are eligible for extended benefits until they reach retirement age (62 years old).

${ }^{4}$ In 2009, the average SA and HA for a single person were $417 € /$ month and $254 € / m o n t h$, respectively. The SA can be applied from the municipality and HA from the KELA.
} 
Table 1

Unemployment benefits in Finland.

\begin{tabular}{lll}
\hline & \multicolumn{1}{c}{$\begin{array}{c}\text { Earnings-related } \\
\text { allowance (UI) }\end{array}$} & Labour market support (LMS) \\
\hline Paid by & Unemployment insurance funds & KELA \\
Eligibility & $\begin{array}{l}\text { member of a fund for at least } 10 \\
\text { months and } 43 \text { weeks of work } \\
\text { during the last } 28 \text { months }\end{array}$ & or UI has been exhausted \\
& 500 days & no limit \\
Maximum duration & 7 days & 5 days \\
Waiting period & no & yes \\
Means tested & yes & yes \\
Taxable income & $55.20 €(1,187 €)$ & $25.63 €(551 €)$ \\
Average daily (monthly) rate & & \\
\hline in 2009 & &
\end{tabular}

Source: Employment and Economic Development Office, KELA

\subsection{Sanctions in Finland}

In Finland, the eligibility conditions for an unemployed individual to receive benefits and to avoid sanctions are: a) register with the public employment service (PES) as an unemployed person, b) actively search for a full-time job, c) apply to jobs suggested by the PES, d) accept ALMPs arranged by PES, e) participate in making a job search plan and f) report to the PES on a regular basis and discuss the job search plan. A compulsory job search plan is created at the beginning of unemployment and specifies how the unemployed will seek work (e.g., which jobs to apply to) and whether ALMP measures are needed to promote employment. Violations of criteria b-f or inadequate search efforts, as evaluated by the PES via interviews ${ }^{5}$, results in sanctions. Sanctions do not reduce the number of benefit entitlement days; benefits are merely postponed by the period of the sanction. In addition, receiving a sanction does not exclude benefits from the time spent in an ALMP measure. Thus, sanctions are intended to encourage unemployed individuals either to find a job or to participate in an ALMP programme.

\footnotetext{
${ }^{5}$ The interviewing interval is case-specific; the interval is typically short (two to four weeks) at the beginning of unemployment and increases as unemployment duration increases (three to six months). The search effort is deemed inadequate, for example, if a jobseeker has not been applying to jobs or has not participated in the ALMP measures recorded in the job search plan.
} 
Most of the sanctions are temporary and have fixed duration of 60 days. In some cases, conditional sanctions (henceforth, 'exclusion of benefits') are imposed, rendering an individual ineligible for unemployment benefits until 90 days of work, education or ALMP measures have been completed. For the long-term unemployed (those unemployed for more than 500 days) and for the young unemployed (those under 25 years of age), the sanctions are stricter: the exclusion of benefits for 150 days.

Table 2 summarises the reasons for and the duration of benefit sanctions. All sanctions entail a $100 \%$ reduction in benefits. Refusal of work leads to 60 days of benefit cessation, but if the duration of the job in question is fewer than five days, then the sanction is reduced to 30 days. Similarly, refusal or dropping out of an ALMP measure and several reasons related to the job search plan lead to a loss of benefits for 60 days. Repeated refusal to comply with any of the requirements (within 12 months) results in a 90-day exclusion of benefits. Except for UI allowance recipients, repeated neglect of the job search plan leads to a 60-day sanction.

It should be noted that in the Finnish benefit system, the severity of a sanction is not always in proportion to the degree of misbehaviour. In certain cases, the duration of unemployment and the type of benefit received influences the strictness of a sanction. Namely, for the long-term unemployed receiving LMS, refusal of work or an ALMP measure or neglect of job search plan agreements results in a 150-day exclusion of benefits. The 150day conditional sanction was introduced on 1 January 2006. It was targeted to those unemployed individuals who have been on LMS for over 500 benefit days or on UI for the maximum 500 benefit days and on LMS for over 180 benefit days thereafter. 
Table 2

Reasons for and duration of benefit sanctions.

\begin{tabular}{lr}
\hline Reason for a benefit sanction & Duration \\
\hline Refusal of work & 60 days $^{\mathrm{a}}$ \\
Refusal of work, fewer than five days & 30 days \\
Refusal or dropping out of ALMP & 60 days $^{\mathrm{a}}$ \\
Repeated refusal of work or ALMP & \\
Job search plan & exclusion of benefits for 90 days \\
- refusal to participate in creating or inspecting a job & 60 days \\
search plan & 60 days $^{\mathrm{a}}$ \\
- neglect of job search plan agreements (refusal of work & \\
and training try-outs, integration measures for & \\
immigrants or work-life preparatory training) & exclusion of benefits for 90 days $^{\mathrm{b}}$ \\
\hline
\end{tabular}

Notes: ${ }^{a}$ The sanction for the young unemployed (individuals under 25 years of age) and for the long-term unemployed (those unemployed for more than 500 days) is the exclusion of benefits for 150 days. ${ }^{\mathrm{b}}$ The sanction for UI benefit recipients is 60 days.

Source: Unemployment Security Act (Työttömyysturvalaki 30.12.2002/1290; 29.12.2005/1217). Available in Finnish at <http://www.finlex.fi/fi/laki/alkup/2002/20021290> (accessed 15 March 2016).

The process of imposing a sanction includes a number of stages. The first stage is the observation of misconduct by the PES caseworker, by a potential employer or by the ALMP programme staff. The second stage begins when the PES notifies the paying authorities about the sanction. In this stage, unemployment benefits immediately cease, and the unemployed individual is informed about the sanction and its duration. During the second phase, the unemployed individual is asked to reflect on the misconduct in writing, typically within a month.

In the third stage, a binding decision regarding the sanction is made by the Labour Commission, which is a committee consisting of representatives of labour and employer organisations. The period between the establishment of noncompliance and the final decision regarding the sanction is typically one to two months. Noncompliance does not always result in a sanction if there is a good, well-documented reason for noncompliance, and in these cases, unemployment benefits are paid retroactively; otherwise, the sanction is continued. The sanctioned individual can appeal to the Unemployment Appeal Board, which typically makes 
a decision within six months. In rare cases, the decision is in favour of the appellant, and the unemployment benefits are paid retroactively. The final level of appeal authority is the Insurance Court.

Table 3

Unemployment benefit sanctions in several European countries.

\begin{tabular}{lll}
\hline Country & Sanction rate, $\%^{\mathrm{a}}$ & Duration and magnitude of a sanction for refusal of \\
& & \\
\hline Finland & 10.2 & 8 weeks, $100 \%$ \\
Sweden & 0.8 & 6 weeks (40 days), $25 \%$ \\
Norway & 10.8 & 8 weeks, $100 \%$ \\
Denmark & 4.3 & 3 weeks, $100 \%$ \\
Netherlands & 36.0 & 8 weeks, $20 \%$ \\
Switzerland & 40.3 & $6-12$ weeks, $100 \%$ \\
Germany & 1.1 & 3 weeks, $100 \%$ \\
\hline
\end{tabular}

Notes: ${ }^{\text {aT }}$ The sanction occurrence rate is defined as sanctions during benefit periods as a percentage of the average stock of benefit claims, 1997-1998 (Gray, 2003). Information for the Netherlands is obtained from Boone and Van Ours (2006).

Source: Grubb (2000), Van den Berg et al. (2004), Van den Berg and Vikström (2014), Douglas et al. (2011)

It is worthwhile to briefly describe how the sanctions in Finland compare to sanctions in other European countries (Table 3). In Norway, the duration of a sanction for the (first) refusal of work is eight weeks, whereas in Denmark and Germany the duration is only three weeks (Grubb, 2000; Douglas et al., 2011). Sweden and the Netherlands represent an exception because the benefits in these countries are only partly reduced (Van den Berg and Vikström, 2014; Van den Berg et al., 2004). Switzerland is the only country that provides warnings to unemployed individuals before implementing sanctions (Lalive et al., 2005). Among the European countries considered, Sweden has the lowest sanction occurrence rate (0.8\%), and Switzerland has the highest rate (40.3\%) (Gray, 2003). Thus, the sanction policies in Finland are average relative to other countries in Europe, at least with respect to the sanction occurrence rate $(10.2 \%)$ and the strictness of sanctions $(100 \%$ reduction for eight weeks). 


\section{Theoretical framework and empirical strategy}

This section briefly describes job search theory and the empirical model that is based on this theory. The expected effect of sanctions on the behaviour of the unemployed and the empirical model for benefit sanctions are both discussed on a general level. The model is described in detail, for example, in Abbring and Van den Berg (2003), Lalive et al. (2005), Abbring et al. (2005) and Van den Berg at al. (2004).

\subsection{Job search theory and benefit sanctions}

The exit rate from unemployment can be analysed using the theory of job search (Mortensen, 1977). During unemployment, a flow of benefits is received, and a flow of search costs must be paid. A jobseeker is able to choose the search intensity $s$ such that job offers arrive and search costs increase according to the rates $\lambda(s)$ and $c(s)$, respectively. Each time a job offer arrives (random drawings from a wage offer distribution $F(w)$ ), an individual must decide whether to accept the job or to continue searching and lose income. To balance the costs of finding a better job, the individual chooses a reservation wage level such that the marginal cost of another period of search is equal to the expected marginal income. The exit rate from unemployment to work, $\theta_{u}$, can be characterised by a reservation wage $\phi$ and optimal search intensity $s^{*}: \theta_{u}=\lambda\left(s^{*}\right)[1-F(\phi)]$.

Sanctions can be introduced into the model by assuming that the rate at which a sanction is imposed is $p(s)$. All individuals may receive sanctions, but the probability of sanctioning decreases as the search effort increases. If an unemployed individual has a lower search intensity level than is required by the system $\left(s^{*}\right)$, then he must decide whether to continue with the reduced search level or to increase efforts to avoid the risk of being caught. The individual knows the relationship between $s$ and $p(s)$, but he does not know in advance when a sanction will be implemented. Thus, the sanction rate can be written as $\theta_{s}=p(s)$, where $p(s)=0$ for $s \geq s^{*}$ and $p(s)>0$ for $s<s^{*}$. In reality, sanctions are also 
implemented for reasons other than inadequate search effort, such as refusal of work or refusal of an ALMP measure offered by the PES. Such refusals can be considered indicators of a low search level $\left(s<s^{*}\right)$, as search intensity is often difficult to measure.

Benefit sanctions affect unemployment duration in two ways. First, the mere risk of being sanctioned may increase the search efforts of unemployed individuals because job search decisions are made based on the expected value of being unemployed (Lalive et al., 2005; Boone et al., 2009). This effect is also known as the ex ante effect or the warning effect. Second, an additional ex post effect emerges when a sanction is imposed (Abbring et al., 2005; Van den Berg et al., 2004). The idea is that a benefit sanction decreases the reservation wage level and increases the search efforts of the jobseeker as a result of the reduced value of being unemployed (i.e., the exclusion of benefits). The effect is temporary because the unemployed individual knows the duration of the sanction; furthermore, as the expiration of the sanction approaches, the reservation wage increases, whereas the search effort of the unemployed individual decreases. However, it is argued that the effect of a sanction may remain positive after expiration of a sanction because of the increased monitoring and additional job search assistance provided by the PES, and because of the desire of the unemployed to avoid future sanctions (e.g., Van den Berg et al., 2004).

The results of the existing studies on the effects of sanctions can be summarised as follows. Abbring et al. (2005) indicate that the incentive effect of a sanction on the jobfinding rate is $58 \%$ for Dutch men and $67 \%$ for Dutch women. Similarly, Svarer (2011) estimates a re-employment rate increase of $123 \%$ for Danish men and $125 \%$ for Danish women. For Switzerland, Lalive et al. (2005) report that the exit rate from unemployment to work increases by $25 \%$ if a sanction warning is issued and by another $20 \%$ if a sanction is actually imposed. In Norway, sanctions increase the re-employment rate by $80 \%$ (Røed and Westlie 2012). Van den Berg and Vikström (2014) find that the effect of sanctions is small in 
Sweden, only approximately $23 \%$. All of these studies are related to UI benefits, and to the best of our knowledge, there is only one study that has additionally considered benefits other than UI. For the Netherlands, Van den Berg et al. (2004) find that sanctions increase the exit rate from SA to work by $148 \%$. The results of Van den Berg et al. (2004) and Abbring et al. (2005) indicate that the effect of sanctions is greater for Dutch unemployed individuals collecting SA than for Dutch unemployed individuals receiving UI benefits.

\subsection{Empirical model for benefit sanctions}

\subsubsection{Timing-of-events model}

We use a timing-of-events model to analyse the effects of benefit sanctions on unemployment duration (Abbring and Van den Berg, 2003). The model allows us to disentangle the selection effects from the causal effects of sanctioning the unemployed. The selection effect is important because the decision to impose a sanction may depend on characteristics of unemployed individuals that are not observable from the data, such as attitude and motivation, which also affect the re-employment rate. The causal effect of sanctions on the exit rate is determined using a mixed proportional hazard (MPH) model and an assumption of non-anticipation. The MPH model is standard in the duration literature (e.g., Van den Berg, 2001). The non-anticipation assumption, which entails that unemployed individuals cannot fully anticipate the actual timing of sanctions, is justified because sanctions in the data are imposed almost immediately after observations of misconduct (see Section 2.2). More justification for the assumption is given in Section 3.2.2.

The timing-of-events model simultaneously estimates an individual's risk of being sanctioned, $h_{s}$, and the hazard of re-employment, $h_{u}$. The two simultaneously estimated functions are as follows: 
$\left.v_{S}\right),(1)$

$$
h_{s}\left(t \mid x_{t}, v_{s}\right)=\exp \left(\beta_{s}^{\prime} x+\varphi_{s} Z^{\prime}(t+\tau)+\alpha_{1} U I_{120}+\alpha_{2} U I_{60}+\alpha_{3} U I_{0}+\lambda_{s}(t)+\right.
$$

$$
\begin{aligned}
h_{u}\left(t \mid t_{s}, t_{e}, x_{t}, v_{u}\right)= & \exp \left(\beta_{u}^{\prime} x+\delta_{1} D_{1}\left(t_{s}<t \leq t_{e}\right)+\delta_{2} D_{2}\left(t_{e}<t\right)+\varphi_{u} Z^{\prime}(t+\tau)+\right. \\
& \left.\alpha_{1} U I_{120}+\alpha_{2} U I_{60}+\alpha_{3} U I_{0}+\lambda_{u}(t)+v_{u}\right),
\end{aligned}
$$

where $\lambda(t)$ is the baseline hazard and $x$ is a function of covariates. The duration of unemployment until the imposition of a sanction is denoted by $t_{s}$, and the duration until the expiration of a sanction is denoted by $t_{e}$.The time-varying indicators for ongoing and completed sanctions are $D_{1}\left(t_{s}<t \leq t_{e}\right)$ and $D_{2}\left(t_{e} \leq t\right)$, respectively. Thus, parameters $\delta_{1}$ and $\delta_{2}$ are our primary interest because they measure the time-varying effects of sanctioning. Furthermore, the baseline hazard is specified as piecewise-constant, indicating that the baseline hazard is allowed to vary between different pre-specified survival time intervals. The changes in the labour market conditions are accounted for by 31 time-varying calendar time (year-quarter) dummies, $Z^{\prime}(t+\tau)$, where $t$ denotes the elapsed duration of unemployment and $\tau$ denotes the calendar time at the beginning of the unemployment spell. Similarly, benefit exhaustion is considered via three time-varying indicators, $U I_{120}(61 \leq r \leq 120), U I_{60}(0<$ $r \leq 60)$ and $U I_{0}(r=0)$, describing the remaining UI benefit days $r$ at time $t$.

The selection effect arises from the correlation between the heterogeneity terms. The unobserved heterogeneity terms, $v_{u}$ and $v_{s}$, are assumed to follow a bivariate discrete distribution. The associated probabilities are denoted as follows:

$$
\begin{aligned}
& p_{1}=\operatorname{Pr}\left(V_{u}=v_{u}^{1}=0, V_{s}=v_{s}^{1}=0\right), \\
& p_{2}=\operatorname{Pr}\left(V_{u}=v_{u}^{1}, V_{s}=v_{s}^{2}\right), \\
& p_{3}=\operatorname{Pr}\left(V_{u}=v_{u}^{2}, V_{s}=v_{s}^{1}\right), \\
& p_{4}=\operatorname{Pr}\left(V_{u}=v_{u}^{2}, V_{s}=v_{s}^{2}\right),
\end{aligned}
$$


where $0 \leq p_{i} \leq 1$ for $i=1, \ldots, 4$ and $\sum_{i=1}^{4} p_{i}=1$. Multiple unemployment spells for the same individuals and the time-varying covariates enhance the identification of the MPH model in the sense that the identification is less dependent on the proportionality assumption (e.g., Gaure et al., 2007; Brinch, 2007).

The log-likelihood function of the model is given in Appendix A.

\subsubsection{The non-anticipation assumption}

A key assumption in the timing-of-events framework is the non-anticipation assumption (NAA) that entails that the date when a sanction will be imposed cannot be anticipated. The assumption is plausible if sanctions are imposed quickly once a failure to comply with job search requirements has taken place.

In the Finnish sanction system, some infringements are easier and faster to observe than others. At the start of the unemployment spell, the jobseeker has to give information about himself (e.g., education and working history), his previous job and the reason he became unemployed. In terms of these characteristics, the jobseeker has to apply for the jobs suggested and accept suitable job offers or training arranged by the unemployment agency. This type of misbehaviour is easy to observe and sanctions can be imposed rather quickly. Instead, the monitoring of job search activity is more difficult, and usually, misbehaviour in this category is detected with a delay. The search activity is evaluated by the PES (at least) every 3-6 months by interviewing the unemployed individual. The unemployed explains to the caseworker how he has looked for work and which jobs or training he has applied during the past months. The search effort is deemed inadequate, for example, if the jobseeker has not been applying to jobs or has not participated in the ALMP measures recorded in the job search plan. The legislation dictates that the search activity has to be evaluated by the PES during the third and sixth month of unemployment, and thereafter every 6 months. However, the interviewing interval is case-specific because the PES can also hold additional meetings. 
In reality, unemployed individuals may receive private signals about the date when the sanction may start, and change their search effort. In the Finnish context, the scheduled meetings with caseworkers could signal a potential sanction to those jobseekers who are aware of their own insufficient search effort. If the meetings are correlated to the timing of sanctions, the NAA may not hold ${ }^{6}$.

It is reasonable to assume that the NAA holds in our study for two reasons. First, the unemployed individuals cannot fully anticipate the actual timing of sanctions because imposing a sanction takes several steps and because administrative delays create uncertainty (see Section 2.2). Second, the interviewing interval is case-specific, andaccording to the data, there is no clear correlation between the timing of a PES meeting and the timing of a sanction. Approximately $46 \%$ of the sanctioned cases had a meeting with a PES caseworker during the same unemployment spell but only $22 \%$ of the sanctioned cases received a sanction within 90 days after the meeting ${ }^{7}$. Moreover, the average duration between the date of a meeting with a caseworker and the starting date of a sanction was 120 days. Thus, it is unlikely that unemployed individuals anticipate the imposition of a sanction, or, at least, the exact date of the sanction.

\section{Data and descriptive evidence}

The micro data that are used in this study are obtained from the Ministry of Employment and the Economy and include information on all persons registered with PES as a jobseeker. ${ }^{8} \mathrm{We}$ focus on unemployed individuals and follow those who enter unemployment

\footnotetext{
${ }^{6}$ The author would like to thank an anonymous referee for pointing this out.

${ }^{7}$ Approximately $9 \%(5 \%)$ of the sanctioned cases received a sanction within 30 days (14 days) after the meeting with a PES caseworker.

${ }^{8} \mathrm{~A}$ person can register as a jobseeker to the PES while being employed but unemployment benefits can be applied only after officially been registered as an unemployed jobseeker - at the earliest during the first day of unemployment. Moreover, there is a 7-day (5-day) waiting period for the UI (LMS) benefits.
} 
during the period from January 12003 to December 31 2009. We determine whether these individuals leave unemployment by the time the observation period ends (December 2010). An unemployment spell (measured in days) is defined as the time between a jobseeker's registration with PES and the jobseeker's finding a job itself or accepting a job offer by PES. The ending dates of unemployment periods have been verified with the employment records from the Finnish Centre for Pensions (ETK). ${ }^{9}$

Some previous studies have used the measure of non-employment duration (Card et al., 2007). We have used the duration of registered unemployment because, first, similar measure has been used in many previous studies (see e.g., Svarer, 2011; Abbring et al., 2005; Lalive et al., 2005; Van den Berg et al., 2004). Second, our unemployment data is unique because it includes information on all Finnish unemployed persons registered at the PES, and it also merges information from other important Finnish authorities. Many of the previous studies on benefit sanctions have used relatively small samples that are often restricted to small geographic areas or even to specific industries (see, e.g., Van den Berg et al., 2004; Lalive et al., 2005; Abbring et al., 2005). And third, the data enable us to compare the effect of sanctions for individuals receiving two different unemployment benefits: earnings-related benefits (UI) and flat-rate labour market support (LMS). Most existing studies have examined the effect of sanctions on unemployment duration for individuals receiving unemployment insurance (UI) benefits.

Importantly, the data include information on sanctions: the reason for sanctions and the starting and ending dates of each sanction. Different types of characteristics of unemployed jobseekers are also reflected in the data, such as, gender, age, education, occupation, UI fund

\footnotetext{
${ }^{9}$ We can see from the data the ending reason of each unemployment spell (found a job, moved to outside the labour force, started education etc.). However, in some cases, the ending reason of a spell was unknown, most likely because the unemployed jobseeker did not inform the PES. Therefore, the employment records form the ETK were used to verify the ending dates of unemployment spells, and also, to verify whether the unknown ending reason of a spell was re-employment.
} 
membership, citizenship, native language and place of residence ${ }^{10}$. Regional unemployment rates are obtained from the Labour Force Survey of Statistics Finland.

From the registers of the Financial Supervisory Authority (FSA) and the KELA, we are able to determine the type of the benefit received by each unemployed individual and the remaining benefit days at the beginning of an unemployment spell. This information is important for several reasons. First, the probability of finding a job is twice as high for those who receive a UI allowance than for those who receive a means-tested allowance (Lilja, 1993). Second, the job search intensity of unemployed individuals increases when the exhaustion date of the UI benefits approaches (e.g., Krueger and Mueller, 2010; Card et al., 2007; Virjo et al., 2006).

We restrict the data as follows. First, we limit the analysis to unemployed individuals between 25 to 49 years of age because the eligibility criteria for individuals under 25 years of age are particularly strict, whereas those for individuals over 50 years of age are rather loose. Second, temporarily laid-off and disabled individuals as well as persons who moved abroad are excluded from the data. Third, unemployment spells at the beginning of an ALMP measure are censored. Fourth, we omit individuals with sanctions that are imposed at the beginning of the unemployment period because the timing-of-events model cannot identify the selectivity involved. Fifth, long unemployment durations are censored from 30 months (2.5 years) onwards. ${ }^{11}$

The resulting sample data consist of more than one million unemployment spells, of which approximately 28,000 spells $(3.1 \%)$ included a sanction period. ${ }^{12}$ The share of

10 Åland, which is an autonomous island, is excluded from the data because of its exceptional labour market conditions.

${ }^{11}$ Approximately $1 \%$ of the unemployment spells have elapsed duration of more than 30 months. We also merge unemployment spells in which the gap between two subsequent spells is smaller than two weeks.

${ }^{12}$ The resulting sample consists of nearly $20 \%$ of all sanction cases during the 2003-2009 period. The share is low because of the restrictions imposed on the data: the exclusion of sanctions imposed at the beginning of the 
sanctions varied from $1.3 \%$ to $4.4 \%$ during the $2003-2009$ period. Nearly $70 \%$ of the sanctions were imposed for 60 days, and over $30 \%$ of the cases led to the exclusion of benefits for 90-150 days (Table 4). Less than $1 \%$ of the sanctions had a duration of 30 days. During the 2003-2009 period, the share of sanctions related to refusal of work decreased, and the share of sanctions related to refusal or dropping out of an ALMP measure increased. Appendix B represents the distribution of sanctions separately for the UI and LMS benefit receivers.

Table 4

Distribution of sanctions by incident and duration.

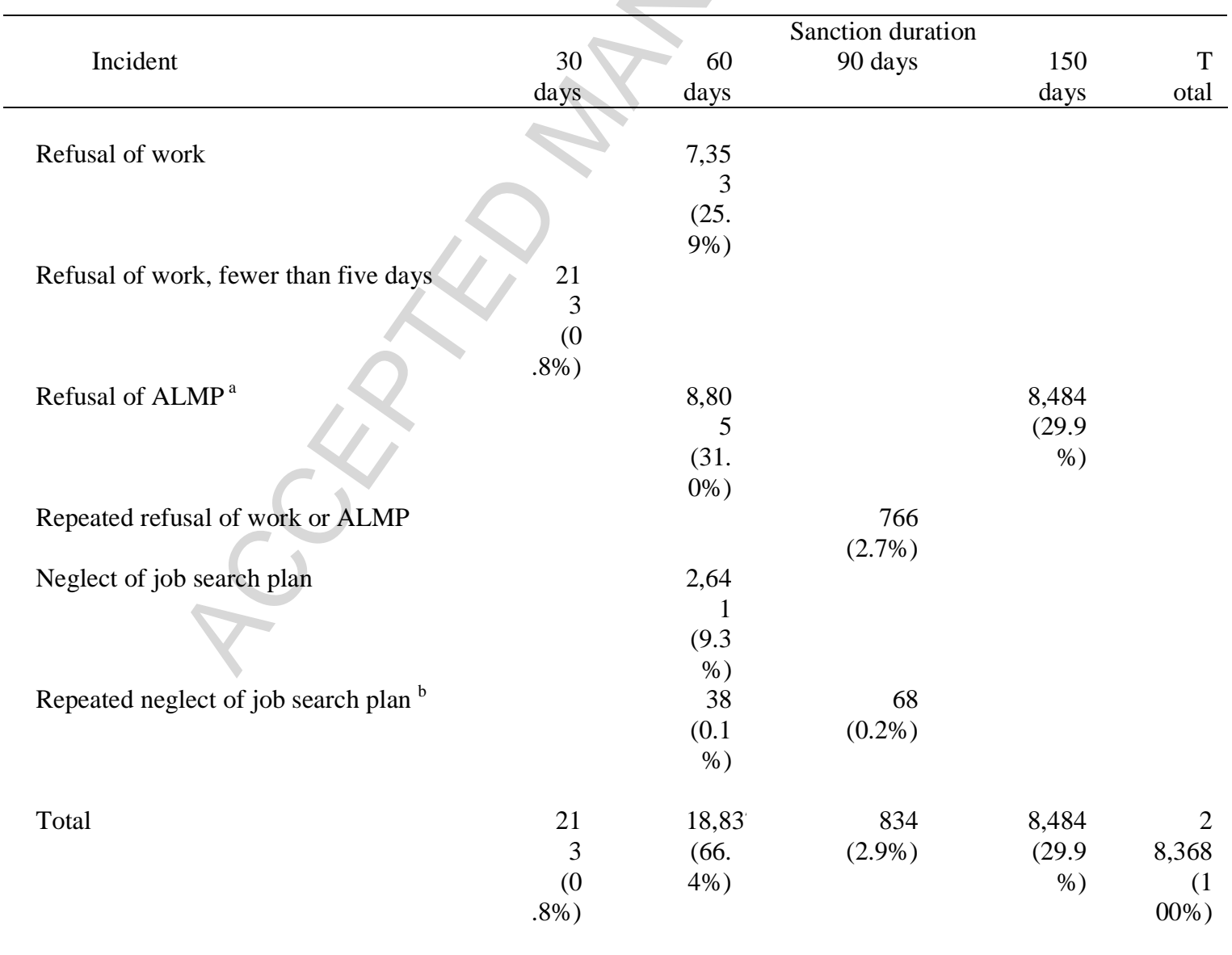

Notes: ${ }^{a}$ The sanction for long-term unemployed individuals (duration of more than 500 days) is the exclusion of benefits until 150 days of work, education or labour market policy measures are performed. ${ }^{\mathrm{b}}$ The sanction for UI benefit recipients is 60 days.

unemployment period (47\%) and the exclusion of sanctions for those under 25 years old (25\%) or over 50 years old (10\%). 
The selected descriptive statistics for UI and LMS are presented in Table 5. These statistics are related to unemployment spells rather than to individuals. Moreover, the descriptive statistics for the non-sanctioned ('no sanction') spells are practically identical to the statistics for the entire population in each sample (UI and LMS) because of the low number of sanctions. Thus, by comparing the non-sanctioned unemployment spells of each sample, we can analyse the differences between UI and LMS recipients. Overall, there appear to be more women and highly educated individuals receiving UI than receiving LMS. Furthermore, more immigrants and individuals aged 25-29 appear to be receiving LMS than UI.

There are approximately 370,000 and 522,000 unemployment spells for UI and LMS recipients, respectively. The exit to work is higher with UI (73\%) than with LMS (58\%). With respect to both types of benefits, more exits from the labour force $(12 \%-15 \%)$ occurred when sanctions were imposed. In addition, sanctioned individuals receiving UI participated in ALMPs (26\%) more often than non-sanctioned individuals (19\%), whereas the opposite applies for LMS. There are fewer women among the group of sanctioned unemployed individuals than among non-sanctioned unemployed individuals, regardless of the benefits received. Similarly, highly educated individuals are sanctioned less frequently than those with lower levels of education.

Many of the unemployed individuals had several periods of unemployment during the observation period. The unemployment history is summarised by the number of unemployment days accumulated within a year and within one to two years prior to the current unemployment period (not presented in Table 5). Most of the sanctioned individuals had relatively little unemployment history (0-49 days) before receiving a sanction, which suggests that there may be some unawareness of the sanction rules. This finding is 
particularly applicable to the UI allowance (49\%). Moreover, UI benefit exhaustion appears to have occurred (during the current unemployment period) more often with sanctioned individuals $(26 \%)$ than with non-sanctioned individuals (8\%). Among the LMS recipients, some individuals (40\%) exhausted their UI benefits prior to the current unemployment period (member of UI fund), and relatively few of these individuals received a sanction (14\%).

Table 5

Selected descriptive statistics (means) for sanctioned and non-sanctioned unemployed individuals by allowance type.

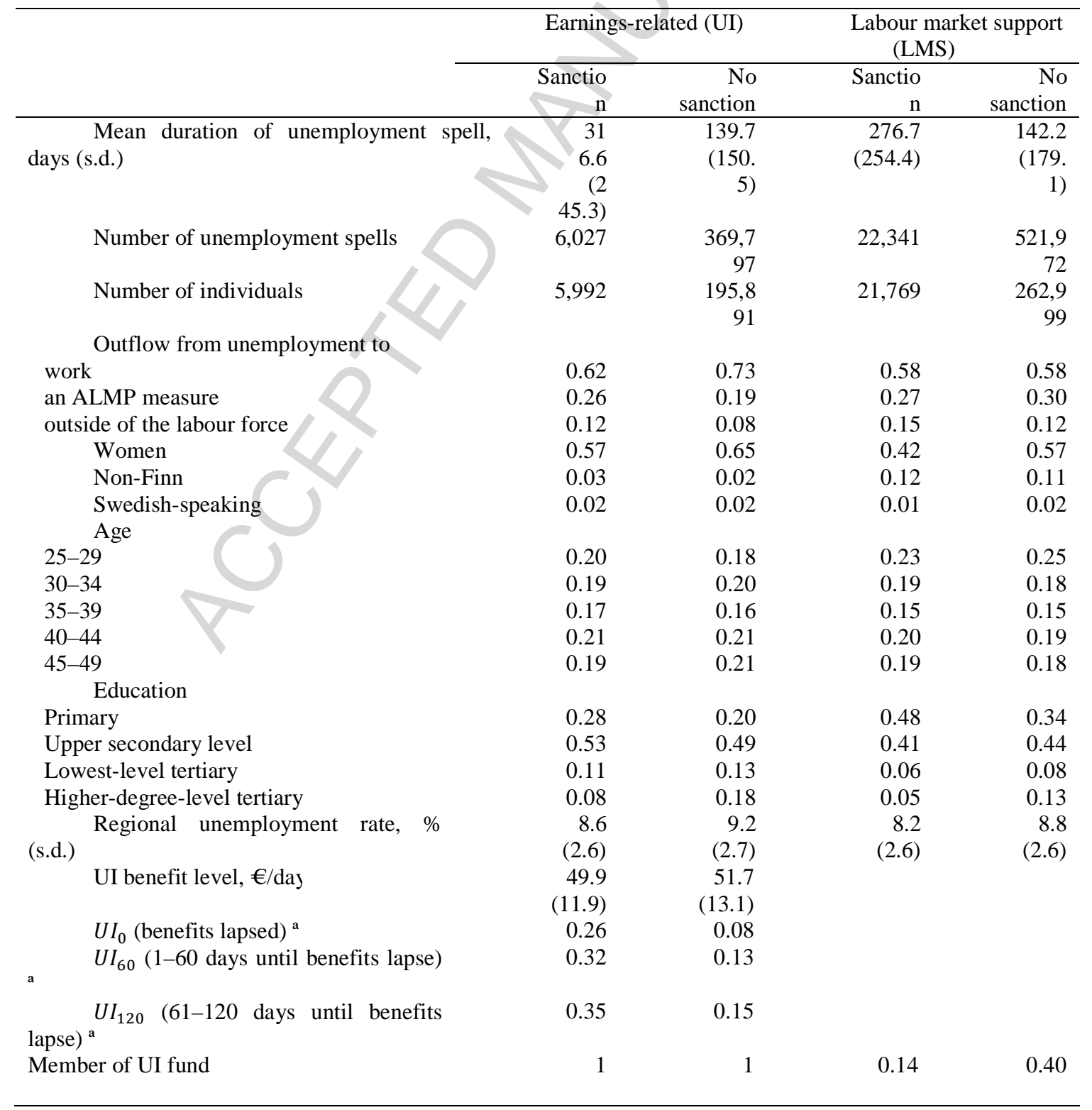

Notes: The statistics are related to unemployment spells. ${ }^{a}$ Measured as time-invariant. 


\section{Graphical evidence of the effect of sanctions}

Figures 1a and $1 \mathrm{~b}$ depict the weekly exit rate from unemployment to work for LMS and UI recipients, respectively, who received a sanction during or before the week in question (sanctioned) and for recipients who did not receive a sanction by that week but may subsequently receive a sanction (non-sanctioned). From the fourth week onwards, the LMS hazard of sanctioned individuals is above the LMS hazard of non-sanctioned individuals, indicating that sanctions increase the re-employment rate (Figure 1a). On average, the jobfinding rate of sanctioned individuals is nearly $80 \%$ higher than that of non-sanctioned individuals. In contrast, the effect of sanctions on the re-employment rate of UI benefit receivers appears to be much smaller, $26 \%$ on average (Figure $1 b$ ).

Figure 2 presents the empirical sanction hazard by allowance type. The probability of receiving a sanction is approximately $0.1 \%$ for UI receivers for the first 10 months (40 weeks), but the sanction rate subsequently begins to increase as the elapsed duration of unemployment increases. ${ }^{13}$ After two years (100 weeks) of unemployment, there is a peak in the sanction rate, most likely resulting from the exhaustion of benefits. For LMS receivers, the sanction rate is higher for the first four months (16 weeks) and decreases thereafter to a steady level of $0.3 \%$. At the end of both of the figures (over 104 weeks) there is significant variation because of the small number of sanctions for long durations of unemployment.

These figures suggest that sanctions have positive effects on the re-employment rate of unemployed individuals but that this effect is larger for LMS recipients than for UI recipients. Nonetheless, the empirical hazards do not account for differences in observed and unobserved characteristics, which are important. These issues are covered in the following section.

\footnotetext{
13 The most common reason for a sanction for an unemployed individual receiving UI is voluntary quitting, which is not considered in this analysis. For individuals receiving LMS, the most common reasons for sanctions are refusal of work and refusal to comply with an ALMP measure.
} 


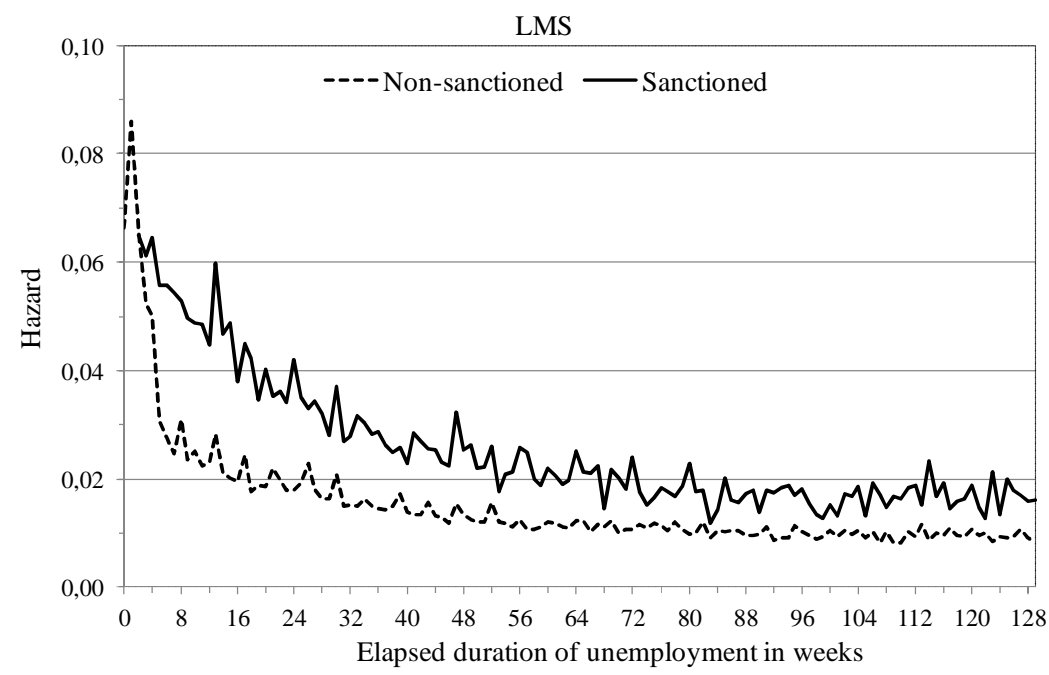

Fig.1a. Empirical exit rates to work for sanctioned and non-sanctioned LMS recipients.

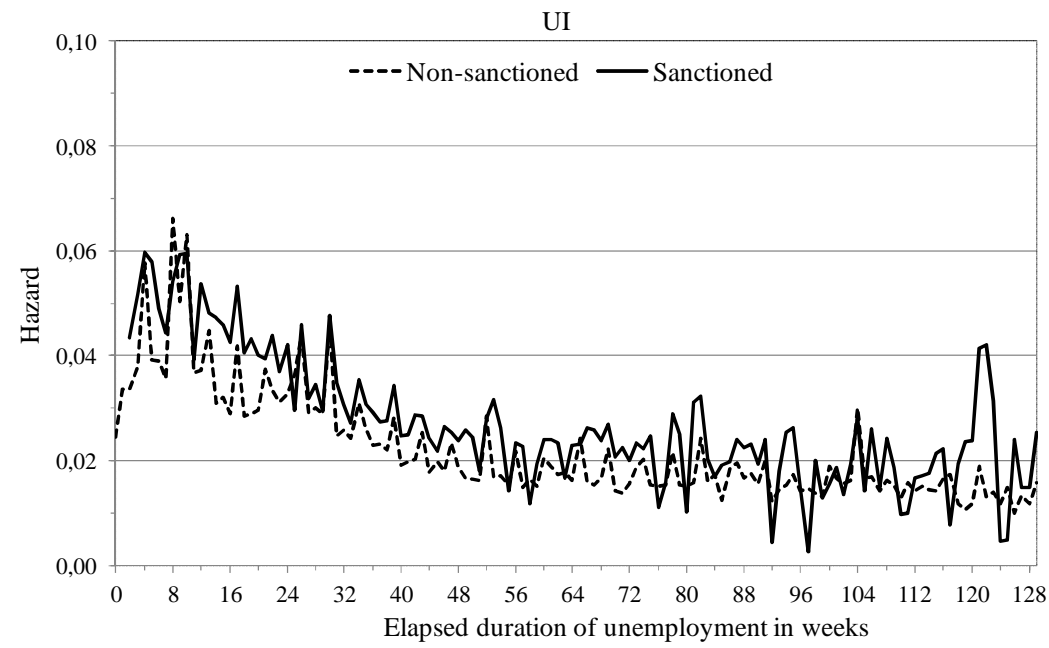

Fig.1b. Empirical exit rates to work for sanctioned and non-sanctioned UI recipients.

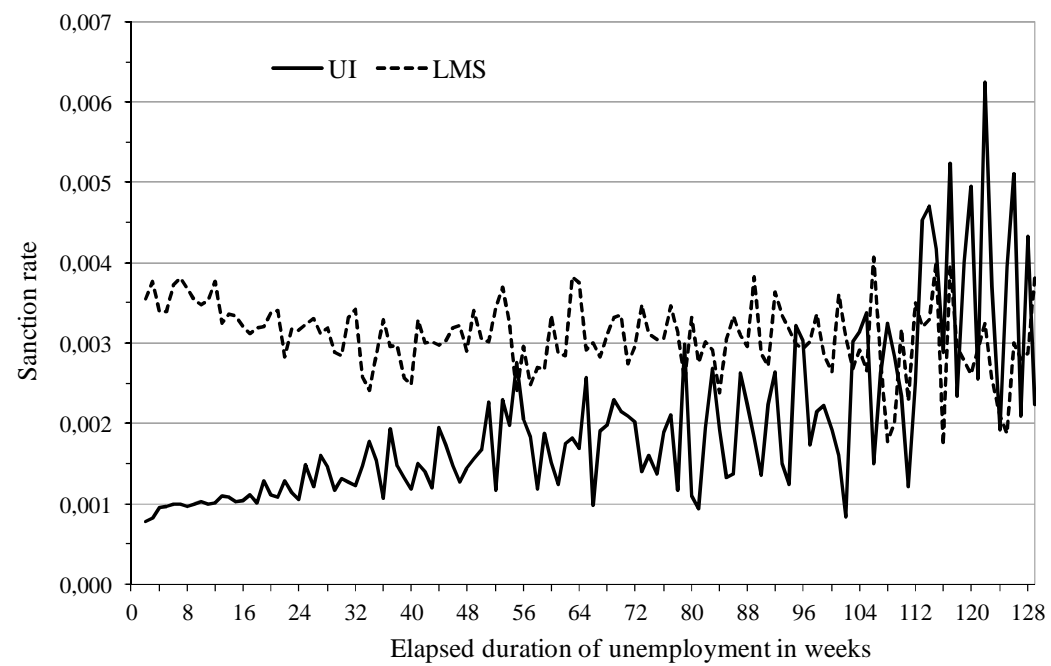

Fig.2. Empirical sanction rate for UI and LMS recipients. 


\section{The effects of sanctions on UI and LMS recipients}

This section analyses whether the imposition of a sanction increases the exit rate from unemployment to work among UI and LMS recipients. ${ }^{14}$ Both models include the same set of explanatory variables, except that for UI, there are also three time-varying indicators for the remaining benefit days, whereas for LMS, there is a variable (member of UI fund) describing whether UI was exhausted at some point during previous unemployment spells. ${ }^{15}$ All exits from unemployment to states other than employment are treated as censored observations. Subsequently, we also analyse the effect of a sanction for various labour market outcomes: exit from unemployment to an ALMP measure and outside of the labour force.

\subsection{Exit rate from unemployment to work}

Table 6 presents the estimation results for the timing-of-events model by allowance type. ${ }^{16}$ The results suggest that unemployed individuals receiving LMS are more responsive to sanctions than UI benefit recipients. When a sanction is imposed, the incentive to find a job increases by $84 \%(100 *(\exp (0.61)-1)=84)$ for unemployed individuals receiving LMS. For individuals collecting UI benefits, the job-finding rate increases by $25 \%$. Completed sanctions also increase the re-employment rate by $34 \%$ with LMS but have no significant

${ }^{14}$ We model the time elapsed until the first sanction was imposed during each unemployment period (for similar approaches, see, e.g., Van den Berg et al. 2004, Abbring et al. 2005, Lalive et al. 2005 and Svarer 2011).

15 Imposition of a sanction may also depend on the characteristics of the employment agency (e.g., Boockmann et al., 2009). Estimating a model with 138 employment agency dummies did not affect the results. The sanction estimates for LMS (UI) receivers was 0.62 (0.19) for an ongoing sanction and $0.29(0.06)$ for a completed sanction. Agency dummies are discarded because the estimation process was computationally demanding and because the results did not change significantly.

${ }^{16}$ We also estimated the models with varying number of mass points. We followed Gaure et al. (2007) and began with a model with $2 \times 2$ mass points and then expanded the model by adding one support point at a time. Adding more than two mass points did not significantly improve the value of the log-likelihood function (as measured by Akaike information criteria). 
effect on UI. The results are surprising because we expected a larger increase in reemployment for individuals receiving UI than for those receiving LMS because of the larger decrease in benefit level. One possibility is that because UI receivers already exhibit high search intensity levels, receiving a sanction does not increase their search intensity, whereas the reverse applies to those receiving LMS. It is also possible that the low number of UI benefit sanctions influences the results.

The estimates of a basic model without correlated heterogeneity are presented in Appendix C. The results imply that neglecting the relation between unobserved heterogeneity terms, $v_{u}$ and $v_{s}$, leads to underestimating the effect of a sanction. However, the bias is relatively small.

Table 6

Results for the timing-of-events model by allowance type.

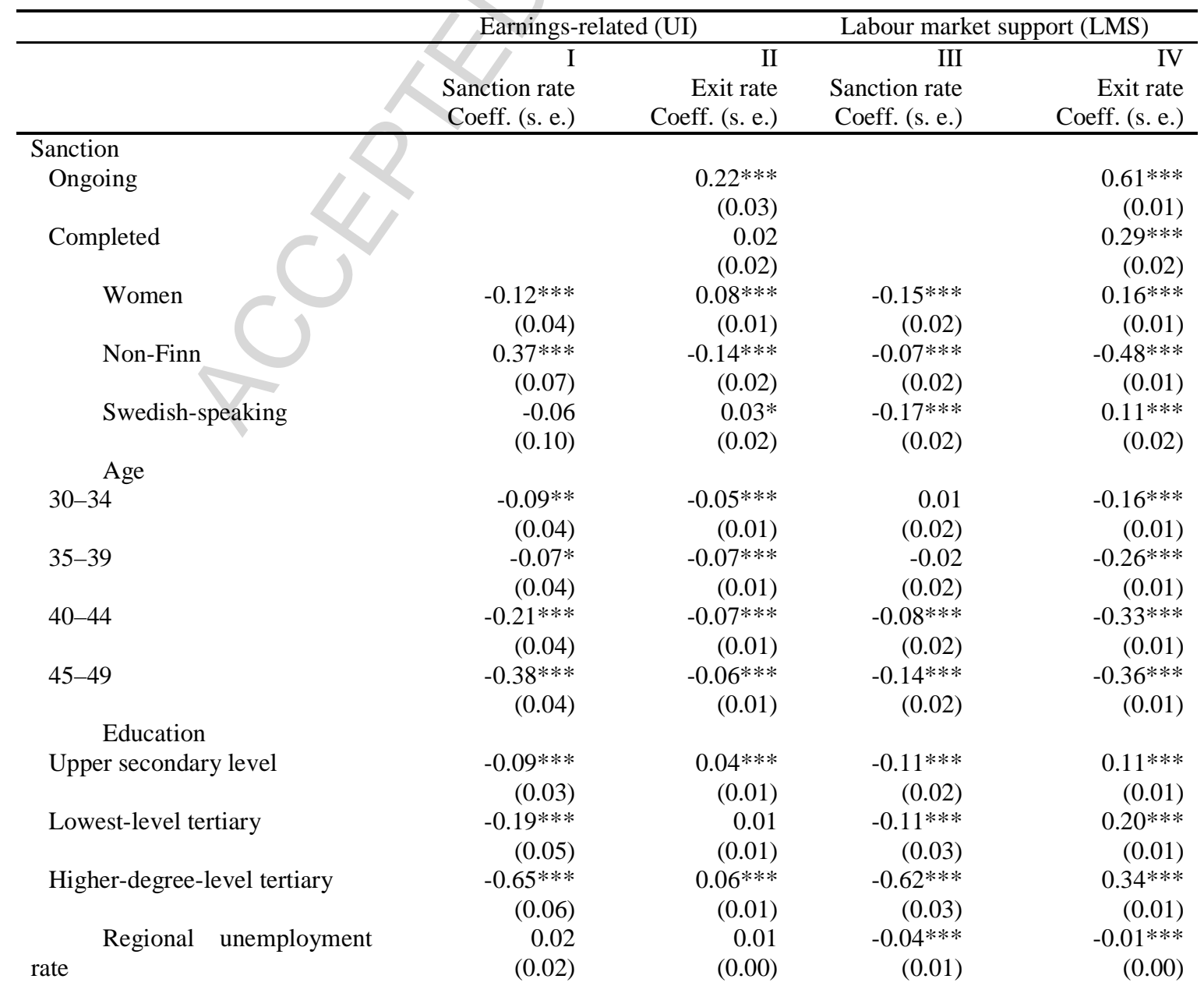


Log(UI benefit level)

$$
\begin{gathered}
U I_{0} \\
U I_{60} \\
U I_{120}
\end{gathered}
$$

Member of UI fund

$$
\begin{array}{rr}
-0.41 * * * & 0.02 * \\
(0.06) & (0.01) \\
-0.24 * * * & 0.22^{* * *} \\
(0.06) & (0.01) \\
-1.12 * * * & 0.37 * * * \\
(0.10) & (0.01) \\
-1.63 * * * & 0.28 * * * \\
(0.11) & (0.01)
\end{array}
$$

\begin{tabular}{|c|c|c|c|c|}
\hline & \multicolumn{2}{|c|}{ Earnings-related (UI) } & \multicolumn{2}{|c|}{ Labour market support (LMS) } \\
\hline & I & II & III & IV \\
\hline & $\begin{array}{l}\text { Sanction rate } \\
\text { Coeff. (s.e.) }\end{array}$ & $\begin{array}{r}\text { Exit rate } \\
\text { Coeff. (s.e.) }\end{array}$ & $\begin{array}{r}\text { Sanction rate } \\
\text { Coeff. (s.e.) }\end{array}$ & $\begin{array}{r}\text { Exit rate } \\
\text { Coeff. (s.e.) }\end{array}$ \\
\hline \multicolumn{5}{|c|}{ Number of unemployment days, $0-1$ year ago } \\
\hline $0-49$ & $\begin{array}{r}-0.24 * * \\
(0.04)\end{array}$ & $3.21 * * *$ & $\begin{array}{r}-0.04 * * \\
(0.02)\end{array}$ & $0.05 * * *$ \\
\hline \multirow{2}{*}{$50-99$} & -0.01 & $1.74 * * *$ & $-0.13 * * *$ & $0.11 * * *$ \\
\hline & $(0.07)$ & $(0.01)$ & $(0.05)$ & $(0.01)$ \\
\hline \multirow[t]{2}{*}{$100-149$} & $.30 * * *$ & $0.93 * * *$ & $-0.14 * *$ & 0.01 \\
\hline & $(0.06)$ & $(0.01)$ & $(0.06)$ & $(0.02)$ \\
\hline \multirow[t]{2}{*}{$150-199$} & $0.13 * *$ & $0.40 * * *$ & -0.03 & $-0.11 * * *$ \\
\hline & $(0.06)$ & $(0.01)$ & $(0.06)$ & $(0.02)$ \\
\hline \multirow[t]{2}{*}{$200-249$} & $0.23 * * *$ & -0.02 & 0.12 & $-0.17 * * *$ \\
\hline & $(0.06)$ & $(0.02)$ & $(0.08)$ & $(0.03)$ \\
\hline \multirow[t]{2}{*}{$250-299$} & $0.22 * * *$ & $-0.34 * * *$ & -0.06 & $-0.16 * * *$ \\
\hline & $(0.07)$ & $(0.02)$ & $(0.12)$ & $(0.05)$ \\
\hline \multicolumn{5}{|c|}{ Number of unemployment days, 1-2 } \\
\hline \multicolumn{5}{|c|}{ years ago } \\
\hline \multirow{2}{*}{$0-49$} & 0.20 & $3.38 * * *$ & $-0.15 * * *$ & $0.18 * * *$ \\
\hline & $(0.58)$ & $(0.03)$ & $(0.06)$ & $(0.01)$ \\
\hline \multirow[t]{2}{*}{$50-99$} & -0.28 & $2.39 * * *$ & $-0.11 *$ & $0.19 * * *$ \\
\hline & $(0.23)$ & $(0.01)$ & $(0.06)$ & $(0.01)$ \\
\hline \multirow[t]{2}{*}{$100-149$} & -0.46 & $1.73 * * *$ & $-0.20 * * *$ & $0.13 * * *$ \\
\hline & $(0.14)$ & $(0.02)$ & $(0.06)$ & $(0.02)$ \\
\hline \multirow[t]{2}{*}{$150-199$} & 0.19 & $1.34 * * *$ & $-0.21 * * *$ & $0.03 *$ \\
\hline & $(0.12)$ & $(0.02)$ & $(0.06)$ & $(0.02)$ \\
\hline \multirow[t]{2}{*}{$200-249$} & 0.04 & $0.97 * * *$ & -0.10 & -0.02 \\
\hline & $(0.12)$ & $(0.02)$ & $(0.06)$ & $(0.02)$ \\
\hline \multirow[t]{2}{*}{$250-299$} & 0.04 & $0.64 * * *$ & -0.09 & $-0.05 * *$ \\
\hline & $(0.12)$ & $(0.01)$ & $(0.07)$ & $(0.02)$ \\
\hline \multirow[t]{2}{*}{ Occupation dummies } & $\mathrm{y}$ & yes & yes & yes \\
\hline & es & & & \\
\hline Place of residence (TE-centre) & $\mathrm{y}$ & yes & yes & yes \\
\hline dummies & es & & & \\
\hline Calendar time dummies & yes & yes & yes & yes \\
\hline \multirow{2}{*}{$v_{s}$} & $-0.74 * * *$ & & $0.26 * * *$ & \\
\hline & $(0.13)$ & & $(0.04)$ & \\
\hline \multirow[t]{2}{*}{$v_{u}$} & & $-1.19 * * *$ & & $-1.69 * * *$ \\
\hline & & $(0.00)$ & & $(0.00)$ \\
\hline \multirow[t]{3}{*}{$p_{1}$} & \multirow{2}{*}{\multicolumn{2}{|c|}{$\begin{array}{l}0.01 * * * \\
(0.00)\end{array}$}} & \multirow{2}{*}{\multicolumn{2}{|c|}{$0.19 * * *$}} \\
\hline & & & & \\
\hline & & $* * *$ & & $0.43 * * *$ \\
\hline
\end{tabular}

$-0.49 * * *$

(0.02)
$1.24 * * *$

(0.00)

Table 6

(continued) 


\begin{tabular}{cll}
\multicolumn{1}{c}{$p_{3}$} & $(0.01)$ & $(0.00)$ \\
$p_{4}$ & $0.12^{* * *}$ & $0.32^{* * *}$ \\
& $(0.00)$ & $(0.00)$ \\
Log likelihood & $0.06^{* * *}$ & $0.05 * * *$ \\
Number of individuals & $(0.01)$ & $(0.00)$ \\
& $-1,680,839$ & $-2,037,936$ \\
& 198,341 & 266,209
\end{tabular}

Notes: To conserve space, estimates for the baseline hazard are not presented. The reference groups are as follows: 25-29 years old (age), primary level (education),300-365 (number of unemployment days, 0-1 year ago, 300-365 (number of unemployment days, 1-2 years ago), unclassified (occupation), Uusimaa (place of residence) and 2005q1 (calendar time). $* * *, * *$ and $*$ indicate significance at the $1 \%, 5 \%$ and $10 \%$ levels, respectively.

The estimation results in columns I and III indicate that with respect to both types of benefits, the probability of receiving a sanction is lower for women and for Swedish-speaking citizens. The sanction rate also decreases when educational level or age increases. Unlike with LMS, immigrants receiving UI are more likely to be sanctioned $(48 \%)$ than natives. In addition, the probability of receiving a sanction rises once UI benefits are exhausted, perhaps because of the increased offering of ALMPs after UI benefits are exhausted.

In the basic timing-of-events model, multiple unemployment spells experienced by the same individual are exploited to enhance the quality of the estimation results. Because individual-level heterogeneity can be a strong assumption, we also estimate a model for which the unobserved heterogeneity was considered at spell level. In this case, the LMS (UI) estimate for an ongoing sanction was $0.62(0.15)$, and the estimate for a completed sanction was $0.35(-0.03)^{17}$. Thus, the results are robust.

As a further sensitivity analysis, we also estimated a model that allows unobserved heterogeneity in the censoring process (see Appendix D and E). The results show that the estimates are robust when endogenous right censoring, that is exits to ALMP and outside the labour force, are taken into account: the LMS (UI) estimate for an ongoing sanction was 0.63 (0.18), and the estimate for a completed sanction was $0.31(-0.01)$.

\footnotetext{
${ }^{17}$ The full results are available from the author.
} 


\subsubsection{The effect of a sanction across the population}

Reactions to sanctions differ among various unemployment groups (Svarer, 2011; Van den Berg et al., 2004). To examine this possibility, we allow sanction dummies to interact with some of the explanatory variables. The results are shown in Table 7 . We also include indicators for the sanction type (duration) in the interaction model. ${ }^{18}$

With both types of benefits, women are less responsive to sanctions than men. According to Hasenfeld et al. (2004), sanctions have no incentive effects if there are personal barriers, such as a lack of work experience and child care demands. Previous studies also indicate that having children decreases the exit rate from unemployment to work for married parents and even more so for single parents (Van den Berg et al., 2004). Having young children has also been observed to prolong the unemployment duration of Finnish women (see, e.g., Ollikainen, 2003; Gonzalo and Saarela, 2000). Unfortunately, information on family-related background characteristics was not available. Similarly, unemployed individuals with higher levels of education react to ongoing sanctions less than their counterparts, but the reverse is true after a sanction is completed. One explanation is that there is a time lag between the moment when an unemployed individual increases his job search effort and the moment when his re-employment rate increases (Van den Berg et al. 2004). Thus, highly educated unemployed individuals may actually be more responsive to sanctions than those with lower education levels because of this delay.

One distinctive difference between the two allowance types is the sanction effect for immigrants. Immigrants receiving LMS are more responsive to sanctions, both ongoing (19\%) and completed (51\%), than natives. The same coefficient for the UI allowance is

\footnotetext{
18 The reference group includes sanctions of 30-60 days. The other category for sanctions is the exclusion of benefits until 90-150 days of work, education or ALMP programmes have been completed by the jobseeker.
} 
negative but statistically insignificant ${ }^{19}$. This result is interesting because immigrants were expected to have longer unemployment durations than Finns regardless of the benefit received (see Table 6). It is possible that immigrants become less selective in their job seeking once they are sanctioned. Immigrants who have limited language skills and who have acquired competence abroad that is not recognised may be willing to accept jobs with low requirements. Furthermore, immigrants may be unaware of the sanction rules and would thus increase their job search efforts after expiration of a sanction because of the closer monitoring and counselling provided by the PES (Hasenfeld et al. 2004; Van den Berg et al. 2004). Such a situation is especially applicable if the duration of residence in the country has been relatively short.

Table 7

Results for the exit rate from unemployment to work with interaction effects.

\begin{tabular}{|c|c|c|c|c|}
\hline \multirow[b]{2}{*}{ Interactions } & \multicolumn{2}{|c|}{ Sanction } & \multicolumn{2}{|c|}{$\begin{array}{l}\text { Labour market support (LMS) } \\
\text { Sanction }\end{array}$} \\
\hline & $\begin{array}{r}\text { Ongoing } \\
\text { Coeff. (s. e.) }\end{array}$ & $\begin{array}{r}\text { Completed } \\
\text { Coeff. (s. e.) }\end{array}$ & $\begin{array}{r}\text { Ongoing } \\
\text { Coeff. (s. e.) }\end{array}$ & $\begin{array}{r}\text { Completed } \\
\text { Coeff. (s. e.) }\end{array}$ \\
\hline \multirow[t]{4}{*}{ Intercept } & $0.47 * * *$ & $0.14^{* *}$ & $0.72 * * *$ & $0.50 * * *$ \\
\hline & $(0.07)$ & $(0.08)$ & $(0.03)$ & (0.04) \\
\hline & $-0.19 * * *$ & -0.04 & $-0.36 * * *$ & $-0.28 * * *$ \\
\hline & $(0.05)$ & $(0.05)$ & $(0.03)$ & $(0.04)$ \\
\hline \multirow[t]{2}{*}{ Non-Finn } & -0.28 & 0.19 & $0.17 * * *$ & $0.41 * * *$ \\
\hline & $(0.18)$ & $(0.13)$ & $(0.05)$ & $(0.06)$ \\
\hline \multirow[t]{2}{*}{ Swedish-speaking } & 0.00 & 0.19 & 0.11 & -0.08 \\
\hline & $(0.21)$ & $(0.17)$ & $(0.10)$ & $(0.16)$ \\
\hline \multicolumn{5}{|l|}{ Age } \\
\hline \multirow[t]{2}{*}{$30-34$} & -0.06 & -0.02 & $0.12 * * *$ & -0.01 \\
\hline & $(0.08)$ & $(0.07)$ & $(0.04)$ & $(0.05)$ \\
\hline \multirow[t]{2}{*}{$35-39$} & $-0.15^{*}$ & $-0.19 * * *$ & $0.08 * *$ & -0.08 \\
\hline & $(0.08)$ & $(0.07)$ & $(0.04)$ & $(0.05)$ \\
\hline \multirow[t]{2}{*}{$40-44$} & $-0.15^{*}$ & $-0.20 * * *$ & $0.12 * * *$ & $-0.15^{* * *}$ \\
\hline & $(0.08)$ & $(0.07)$ & $(0.04)$ & $(0.06)$ \\
\hline \multirow[t]{2}{*}{$45-49$} & $-0.24 * *$ & $-0.25 * * *$ & 0.01 & $-0.19 * *$ \\
\hline & $(0.08)$ & $(0.07)$ & $(0.04)$ & $(0.06)$ \\
\hline \multicolumn{5}{|l|}{ Education } \\
\hline \multirow[t]{2}{*}{ Upper secondary level } & 0.00 & -0.03 & $-0.15 * * *$ & $-0.09 * *$ \\
\hline & $(0.06)$ & $(0.05)$ & $(0.03)$ & $(0.04)$ \\
\hline \multirow[t]{2}{*}{ Lowest-level tertiary } & $-0.18^{*}$ & $0.24 * * *$ & $-0.26 * * *$ & $-0.21 * * *$ \\
\hline & $(0.11)$ & $(0.09)$ & $(0.06)$ & $(0.08)$ \\
\hline \multirow[t]{2}{*}{ Higher-degree-level tertiary } & -0.11 & $0.17 *$ & $-0.29 * * *$ & 0.06 \\
\hline & $(0.11)$ & $(0.09)$ & $(0.06)$ & $(0.08)$ \\
\hline
\end{tabular}

19 Most likely due to small number of observations (see Table 5). Only $2 \%$ of the UI beneficiaries are immigrants. 


\begin{abstract}
Sanction type
90-150 days

$0.26^{*}$

(0.15)

Log likelihood

Number of individuals

$-1,670,801$

198,341

(0.03)

$-2,038,194$

266,209

Notes: The full set of results is available from the author. $* * * * *$ and $*$ indicate significance at the $1 \%, 5 \%$ and $10 \%$ levels, respectively. $\dagger$ It is not possible to complete a sanction without studying, working or participating in an ALMP measure.
\end{abstract}

\title{
5.1.2. The strictness of a sanction
}

The empirical evidence relating to the severity of sanctions is scarce and inconclusive. Svarer (2011) reports that tougher sanctions (three weeks) have greater effects on the reemployment rate than milder sanctions (two to three days). Van den Berg et al. (2004) find that the strictness of a sanction is insignificant because the effects are fairly similar regardless of the magnitude of the benefit reduction $(5 \%, 10 \%$ or $20 \%)$. In this paper, the strictness is measured by the duration of a sanction because all sanctions entail a $100 \%$ reduction in benefits.

Table 8 depicts results for different types of sanctions. We estimate two separate models for each allowance and observe the interaction of the sanction type indicator (30-60 days or 90-150 days) with the time-varying sanction dummies (ongoing and completed). ${ }^{20} \mathrm{We}$ combine the 30-day and 60-day sanctions into one category because of the small number of observations for the 30-day sanction. The other category for sanctions is the exclusion of benefits until 90-150 days of work, education or ALMPs have been completed by the jobseeker. In this category, we estimate the effect of an ongoing sanction because it is not possible to complete a sanction and receive benefits again without studying, working or participating in an ALMP programme. Most of the severe sanctions (90-150 days) in the data are imposed on the long-term unemployed, that is, on unemployed individuals who have

\footnotetext{
${ }^{20}$ The sanction rate is common to both sanction types because there were too few observations for the long sanctions to estimate a separate sanction rate.
} 
exhausted their UI benefits and received LMS thereafter or individuals who have been receiving LMS for more than 500 days. These individuals are monitored more closely, and ALMPs are offered to them more frequently. Thus, it is relevant to investigate whether short (30-60 days) and long (90-150 days) sanctions have similar effects for the two types of benefits considered.

According to the results, the strictness of a sanction is more marked for unemployed individuals receiving LMS. Longer sanctions increase the re-employment rate by $90 \%$, and shorter sanctions increase the re-employment rate by $57 \%$ (Table 8 ). With UI benefits, the effect of longer sanctions on re-employment is $70 \%$, and the effect of brief sanctions is $22 \%$.

It should be noted that with UI benefits, the standard error of longer sanctions is relatively large, most likely because of the low number of observations (see Appendix B). Less than three percent of the UI sanctions are strict (90-150 days). Therefore, these results should be interpreted with some caution. For UI benefits, the sanction effect is primarily driven by the 30- to 60-day sanctions, and this effect is relatively low compared to LMS recipients.

Table 8

Results for the exit rate from unemployment to work and the effects of sanction by type.

\begin{tabular}{|c|c|c|c|c|}
\hline & \multicolumn{2}{|c|}{$\begin{array}{l}\text { Earnings-related (UI) } \\
\text { Sanction type }\end{array}$} & \multicolumn{2}{|c|}{$\begin{array}{l}\text { Labour market support (LMS) } \\
\text { Sanction type }\end{array}$} \\
\hline & $\begin{array}{r}30-60 \text { days } \\
\text { Coeff. (s. e.) }\end{array}$ & $\begin{array}{l}90-150 \text { days } \\
\text { Coeff. (s. e.) }\end{array}$ & $\begin{array}{r}30-60 \text { days } \\
\text { Coeff. (s. e.) }\end{array}$ & $\begin{array}{l}90-150 \text { days } \\
\text { Coeff. (s. e.) }\end{array}$ \\
\hline Sanction & & & & \\
\hline Ongoing & $\begin{array}{r}0.20 * * * \\
(0.03)\end{array}$ & $\begin{array}{r}0.53 * * * \\
(0.15)\end{array}$ & $\begin{array}{r}0.45 * * * \\
(0.02)\end{array}$ & $\begin{array}{r}0.64 * * * \\
(0.02)\end{array}$ \\
\hline Completed & $\begin{array}{r}0.01 \\
(0.01)\end{array}$ & $\dagger$ & $\begin{array}{r}0.21 * * * \\
(0.02)\end{array}$ & $\dagger$ \\
\hline Log likelihood & $-1,671,050$ & $-1,671,067$ & $-2,039,098$ & $-2,038,753$ \\
\hline
\end{tabular}

Notes: The full set of results is available from the author. ***,** and * indicate significance at the $1 \%, 5 \%$ and $10 \%$ levels, respectively. $\dagger$ It is not possible to complete a sanction without studying, working or participating in an ALMP measure.

\subsubsection{The effect of a sanction over time}


The empirical evidence for the time-varying effects of sanctions is inconclusive. Svarer (2011) finds that the effect is strong and positive during the first two months but diminishes three months after the imposition of a sanction. Similarly, Røed and Westlie (2012) note that the effect is relatively short-lived because once the sanction is completed, the hazard of reemployment is at its previous pre-sanction level. In contrast, Van den Berg et al. (2004) find that most of the increase in the job-finding rate occurs after sanction expiration. Furthermore, Müller and Steiner (2008) and Van den Berg and Vikström (2014) provide supporting evidence of the long-term effects of benefit sanctions.

Next, we examine when the effect diminishes after the expiration of a sanction and whether the effect varies during a sanction. We estimate a model in which the effect of a sanction can change one, two, three, four and five months after the imposition of a sanction and one, two and three months after the completion of sanctioning. Because the duration of a sanction is observed to be significant (Table 8), we estimate the model for 30- to 60-day sanctions and for 90- to 150-day sanctions separately for LMS. For UI receivers, we analyse only the time-varying effects for short sanctions because of the low number of observations. As in Table 8, the sanction type indicators are allowed to interact with the time-varying sanction dummies (five for ongoing sanctions and three for completed sanctions).

For LMS recipients, a sanction has a large and positive effect on the job-finding rate both during and after a sanction period (Table 9). For sanctions from 30 to 60 days, the effect is greatest $(51 \%)$ two months after imposition and begins to diminish three months after the expiration date. With sanctions from 90 to 150 days, the effect is greatest (148\%) three months after imposition but remains positive throughout the sanction period. In contrast, for UI recipients, the sanction effect is short-lived because the re-employment rate becomes close to zero or negative as soon as the sanction is completed. 
There are several explanations for these results. First, some time is needed before the adjusted job search intensity of an unemployed individual becomes effective (e.g., because of the recruiting process). Second, closer monitoring of a sanctioned unemployed individual and the individual's willingness to prevent future sanctions may affect the results. 
Table 9

Results for the exit rate from unemployment to work and the effects of sanctions over time.

\begin{tabular}{|c|c|c|c|}
\hline \multirow[b]{3}{*}{ Sanction effects over time } & \multirow{2}{*}{$\begin{array}{r}\text { Earnings-related (UI) } \\
30-60 \text { days }\end{array}$} & \multicolumn{2}{|c|}{ Labour market support (LMS) } \\
\hline & & 30-60 days & 90-150 days \\
\hline & Coeff. (s. e.) & Coeff. (s. e.) & Coeff. (s. e.) \\
\hline \multicolumn{4}{|c|}{ Ongoing, time after imposition in days } \\
\hline $1-30$ & $0.29 * * *(0.03)$ & $0.33 * * *(0.02)$ & $0.55 * * *(0.03)$ \\
\hline $31-60$ & $0.07(0.05)$ & $0.41 * * *(0.03)$ & $0.32 * * *(0.04)$ \\
\hline $61-90$ & & & $0.91 * * *(0.04)$ \\
\hline $91-120$ & & & $0.51 * * *(0.05)$ \\
\hline $121-$ & & & $0.58 * * *(0.02)$ \\
\hline \multicolumn{4}{|c|}{ Completed, time after expiration in days } \\
\hline $1-30$ & $0.09(0.05)$ & $0.35 * * *(0.04)$ & $\dagger$ \\
\hline $31-60$ & $-0.24 * * *(0.07)$ & $0.45 * * *(0.04)$ & $\dagger$ \\
\hline $61-$ & $0.03(0.03)$ & $0.08 * * *(0.02)$ & $\dagger$ \\
\hline Log-likelihood & $-1,671,053$ & $-1,983,416$ & $-1,983,001$ \\
\hline Number of individuals & 198,341 & 266,209 & 266,209 \\
\hline
\end{tabular}

\subsection{Exit rate from unemployment to various labour market outcomes}

Sanctions increase not only the exit rate from unemployment to work but also the exit to non-employment. Arni et al. (2012) discover that the exit rate from unemployment to nonemployment increases by $89 \%$ if a sanction warning is issued and by another $67 \%$ if a sanction is actually imposed. Similarly, Hillmann and Hohenleitner (2012) find that sanctions increase the transition rate to non-employment by $79 \%$. The recent work of Røed and Westlie (2012) reports that sanctions increase not only the exit rate from unemployment to work (80\%) but also the exit to education (200\%) and to an ALMP programme (22\%). The authors also find that the hazard spikes encountered at the time of UI benefit exhaustion partly result from exits from the labour force, primarily to obtain education and other benefits (SA).

We estimate separate models for various labour market outcomes to determine whether there are differences between UI and LMS recipients. Three separate outcomes are considered: exit from unemployment i) to work, ii) to an ALMP and iii) to outside of the 
labour force ${ }^{21}$. It should be noted that the results for the exit to work are the same as in Table 6. The results concerning ALMP are of interest because unemployed individuals can receive benefits from the time that they enter an ALMP programme even after receiving a sanction, which should encourage unemployed individuals to participate in these measures.

According to the results, the probability of participating in an ALMP after receiving a sanction increases by $11 \%$ for LMS recipients but has no effect on UI recipients (Table 10). Expired sanctions have no effect (UI) or very small positive effect (LMS) on the rate of transition to ALMPs. With both benefit types, sanctions encourage unemployed individuals to leave the labour force, but with UI recipients, the incentive is especially strong $(82 \%) .{ }^{22}$ Some individuals may collect unemployment benefits while they wait for a planned education programme or job to begin. In these cases, individuals may simply move outside of the labour force (and apply for social benefits) when they receive a sanction. Exits to outside the labour force may also be only temporary, and thus, they can be considered as unpaid prolongation of unemployment (Arni et al., 2012). This view is supported by the recent literature on the non take-up of unemployment insurance (e.g., Blasco and Fontaine, 2012; Kroft, 2008). ${ }^{23}$

Interestingly, unlike the results relating to exit to work, the probability of participating in an ALMP or exiting the labour force is much larger for women and immigrants than for men and natives. ${ }^{24}$ Especially for women receiving UI benefits, exit to outside of the labour force is more likely than exit to work. For immigrants, both receiving UI or LMS, the probability of participating in an ALMP measure is much larger than the probability to find

\footnotetext{
${ }^{21}$ As a sensitivity analysis, we also estimated models that allow unobserved heterogeneity in the censoring process. The results (available from the author) are robust.

${ }^{22}$ It should be noted that only $12 \%(15 \%)$ of the UI (LMS) recipients exits to outside of the labour force (see Table 5).

23 Not all eligible individuals claim their unemployment benefits. For instance, when a worker expects a relatively low unemployment duration he has few incentives to participate in the unemployment insurance system.

${ }^{24}$ These results are not shown in Table 10 but are available from the author.
} 
work. These findings suggest that these groups of people, especially immigrants, may be less employable than others and that they need ALMPs to enhance their employment opportunities. In addition, family-related reasons may influence the decisions of women to leave the labour force. Previous studies show that having children decreases the exit rate from unemployment to work for married parents and even more so for single parents (Van den Berg et al., 2004; Ollikainen, 2003). In Finland, it has also been argued that the 500-day entitlement period for UI benefits makes unemployed individuals passive and that the benefits are sometimes used for purposes other than active job searching, e.g., to support child care at home (Virjo et al., 2006). It could be that the benefit sanctions do not affect the exit-to-workrates of UI recipients strongly because sanctions are less important for them, for instance, due to good employment prospects, precautionary savings and/or spouse's income. The LMS is means-tested whereas the UI benefit is not, which means that the spouse's income affects the eligibility for the LMS but not for the UI benefits. 
Table 10

Results for various labour market outcomes.

\begin{tabular}{|c|c|c|c|c|c|c|}
\hline & \multicolumn{3}{|c|}{ Earnings-related (UI) } & \multicolumn{3}{|c|}{ Labour market support (LMS) } \\
\hline & Work & ALMP & Outside labour force & Work & ALMP & Outside labour force \\
\hline & Coeff. (s. e.) & Coeff. (s. e.) & Coeff. (s. e.) & Coeff. (s. e.) & Coeff. (s. e.) & Coeff. (s. e.) \\
\hline \multicolumn{7}{|l|}{ Sanction } \\
\hline \multirow[t]{2}{*}{ Ongoing } & $0.22 * * *$ & 0.05 & $0.60 * * *$ & $0.61 * * *$ & $0.10 * * *$ & $0.46 * * *$ \\
\hline & $(0.03)$ & $(0.05)$ & $(0.07)$ & $(0.01)$ & $(0.02)$ & $(0.03)$ \\
\hline \multirow[t]{2}{*}{ Completed } & 0.02 & 0.03 & 0.04 & $0.29 * * *$ & $0.04 *$ & $0.24 * * *$ \\
\hline & $(0.02)$ & $(0.04)$ & $(0.06)$ & $(0.02)$ & $(0.02)$ & $(0.03)$ \\
\hline \multirow[t]{2}{*}{$v_{s}$} & $-0.74 * * *$ & -0.33 & 0.07 & $0.26 * * *$ & -0.02 & $0.32 * * *$ \\
\hline & $(0.13)$ & (2.66) & $(0.61)$ & $(0.04)$ & $(0.82)$ & $(0.04)$ \\
\hline \multirow[t]{2}{*}{$v_{u}$} & $-1.19 * * *$ & $-1.35 * * *$ & $-1.60 * * *$ & $-1.69 * * *$ & $-1.26 * * *$ & $-1.79 * * *$ \\
\hline & $(0.00)$ & $(0.02)$ & $(0.04)$ & $(0.00)$ & $(0.01)$ & $(0.01)$ \\
\hline \multirow[t]{2}{*}{$p_{1}$} & $0.01 * * *$ & $0.22 * * *$ & $0.08 * * *$ & $0.19 * * *$ & $0.13^{* * *}$ & $0.20 * * *$ \\
\hline & $(0.00)$ & $(0.01)$ & $(0.01)$ & $(0.00)$ & $(0.01)$ & $(0.01)$ \\
\hline \multirow[t]{2}{*}{$p_{2}$} & $0.81 * * *$ & $0.42 * * *$ & $0.77 * * *$ & $0.43 * * *$ & $0.16^{* * *}$ & $0.00 * * *$ \\
\hline & $(0.01)$ & $(0.05)$ & $(0.02)$ & $(0.00)$ & $(0.02)$ & $(0.00)$ \\
\hline \multirow[t]{2}{*}{$p_{3}$} & $0.12 * * *$ & $0.03 * * *$ & $0.04 * * *$ & $0.32 * * *$ & $0.27 * * *$ & $0.00 * * *$ \\
\hline & $(0.00)$ & $(0.01)$ & $(0.01)$ & $(0.00)$ & $(0.01)$ & $(0.00)$ \\
\hline \multirow[t]{2}{*}{$p_{4}$} & $0.06^{* * *}$ & $0.33 * * *$ & $0.11 * * *$ & $0.05 * * *$ & $0.44 * * *$ & $0.80 * * *$ \\
\hline & $(0.01)$ & $(0.05)$ & $(0.01)$ & $(0.00)$ & $(0.03)$ & $(0.01)$ \\
\hline Log likelihood & $-1,680,839$ & $-568,737$ & $-311,189$ & $-2,037,936$ & $-1,282,997$ & $-695,864$ \\
\hline $\begin{array}{l}\text { Number of } \\
\text { individuals }\end{array}$ & & 198,341 & & & 266,209 & \\
\hline
\end{tabular}




\section{Conclusions}

This study investigated benefit sanctions and their effect on the exit rate from unemployment to work in Finland. The effect of a sanction on the exit rate was analysed using a timing-of-events model that allowed us to separate the selection and causal effects of sanctioning. We used novel register data, including information on the unemployed at PES during the 2003-2009 period. The data include not only members of unemployment insurance funds but also other unemployed individuals and their benefits, which is uncommon in the literature. Thus, we analysed the effect of sanctions separately for earnings-related allowance (UI) and flat-rate labour market support (LMS) recipients. We also estimated a separate model for various labour market outcomes.

According to the results, LMS recipients react to sanctions more strongly than UI recipients do. An ongoing sanction increases the job-finding rate of UI recipients by $25 \%$ and that of LMS recipients by $84 \%$. A completed sanction also increases the re-employment rate of LMS recipients (34\%) but has no effect on UI recipients. The results are consistent with the findings of previous studies in that the effect of a sanction is much greater for LMS (social assistance) recipients than for UI recipients. ${ }^{25}$ However, relating the results to the previous literature is difficult because of the scarcity of existing evidence on this matter.

In this paper, we also estimated the effect of sanctions on the exit rate from unemployment to an ALMP programme and outside of the labour force. The probability of participating in an ALMP after receiving a sanction increases by $11 \%$ for LMS recipients but has no effect on UI recipients. We also found that UI recipients who receive sanctions are more than three times more likely to exit the labour force $(82 \%)$ than to return to work $(25 \%)$.

\footnotetext{
${ }^{25}$ Abbring et al. (2005) report that the effect of sanctions is $58 \%-67 \%$ for Dutch men and women collecting UI benefits, whereas Van den Berg et al. (2004) find that sanctions increase the exit rate from social assistance to work by $148 \%$. To our knowledge, the study by Van den Berg et al. (2004) is the only study related to sanctions other than UI benefit sanctions.
} 
The results are in line with Arni et al. (2012) who also find that an announcement of a sanction leads to more marked rise in the exit to non-employment rate $(89 \%)$ than in the exit to work rate (17\%). Similarly, Hillmann and Hohenleitner (2012) find that sanctions increase the transition rate to non-employment by almost $80 \%$. It is possible that some individuals collect unemployment benefits while they wait for a planned education or job to begin, and leave the labour force when they receive a sanction. Moreover, exits to outside the labour force might be only temporary, and thus, they can be considered as unpaid prolongation of unemployment (Arni et al., 2012). This view is supported by the literature on the non take-up of unemployment insurance (e.g., Kroft, 2008; Anderson and Meyer, 1997).

Overall, the two benefit groups analysed differ substantially. The results may reflect that LMS recipients are more dependent on unemployment benefits than UI recipients are. Over half of the LMS recipients also receive other forms of social assistance (SA and/or HA), whereas only $10 \%$ of UI recipients receive such assistance (Hannikainen-Ingman et al., 2012; Virjo et al., 2006). Family-related characteristics may also be a factor because the LMS is means-tested whereas the UI benefit is not. Thus, it could be that the benefit sanctions do not affect the exit rates of UI recipients strongly because sanctions are less important for the UI recipients (e.g., due to precautionary savings and/or spouse's income). Instead, the benefit sanctions provide more activation to flat-rate LMS but perhaps at substantially higher cost because LMS recipients are liquidity constrained.

In the Finnish sanction system, the severity of a sanction is not always in proportion to the degree of misbehaviour because the duration of unemployment and the type of benefit received influences to the strictness of a sanction. ${ }^{26}$ This type of sanction system may lead to

\footnotetext{
${ }^{26}$ For the long-term unemployed who have been on LMS for over 500 benefit days or on UI for the maximum 500 benefit days and on LMS for over 180 benefit days thereafter, refusal of work or an ALMP measure results in a 150-day exclusion of benefits (conditional sanction). Normally, refusal of work or an ALMP measure lead to a loss of benefits for 60 days (fixed duration). See section 2.2 for more information.
} 
trade-off between activation and individual welfare, which is something that policy makers should consider. Also, more attention should be given to the UI recipients i) because the sanction rate and the responsiveness to sanctions of these individuals are relatively low compared to individuals receiving flat-rate LMS, and ii) because sanctions seem to be less important for the UI recipients since exits to outside the labour force are more likely than exits to re-employment.

Previous studies report that sanctioned individuals often accept jobs with lower earnings and shorter durations than non-sanctioned individuals do (e.g., Van den Berg and Vikström, 2014; Arni et al., 2012). Finnish unemployed individuals have been found to accept jobs that do not increase (and may even reduce) their household disposable income (Kyyrä, 1999). The effect of sanctions on the quality of subsequent jobs should be examined in the future.

\section{Acknowledgements}

The author would like to thank the anonymous referees, Jaakko Pehkonen, Roope Uusitalo, colleagues at the Pellervo Economic Research PTT and participants in various seminars for their useful comments and suggestions. Special gratitude is extended to Tomi Kyyrä for invaluable assistance with the timing-of-events model. Financial support from the Alfred Kordelin Foundation is gratefully acknowledged. The author is grateful for the hospitality enjoyed at the Government Institute for Economic Research (VATT). Acquiring the research data was part of the project (no.133930) financed by the Academy of Finland. 


\section{Appendix A. The log-likelihood function}

The log-likelihood function of the timing-of-events model can be written as:

$$
\mathcal{L}=\log \left[\sum p_{i} h_{u}\left(t \mid t_{s}, t_{e}, x_{t}, v_{u}^{i}\right)^{c_{u}} S_{u}\left(t \mid t_{s}, t_{e}, x, v_{u}^{i}\right) h_{s}\left(t \mid x_{t}, v_{s}^{i}\right)^{c_{s}} S_{s}\left(t \mid x, v_{s}^{i}\right)\right](2)
$$

where the censoring indicator is denoted by $c$, so that it equals 0 if an unemployment spell is censored and 1 otherwise.

\section{Appendix B. Distribution of sanctions by incident, duration and allowance type}

\begin{tabular}{|c|c|c|c|c|c|}
\hline \multirow[b]{2}{*}{ Incident } & & \multicolumn{2}{|c|}{ Sanction duration } & \multirow[b]{2}{*}{ Total } \\
\hline & 30 days & 60 days & 90 days & 150 days & \\
\hline \multicolumn{6}{|l|}{ Earnings-related (UI) } \\
\hline Refusal of work & & $\begin{array}{l}3,223 \\
(53.5 \%)\end{array}$ & & & \\
\hline \multicolumn{6}{|l|}{ Refusal of work, fewer than five days } \\
\hline Refusal of ALMP ${ }^{a}$ & & $\begin{array}{l}2,148 \\
(35.6 \%)\end{array}$ & & $\begin{array}{l}117 \\
(1.9 \%)\end{array}$ & \\
\hline Repeated refusal of work or & & & $\begin{array}{l}44 \\
(0.7 \%)\end{array}$ & & \\
\hline Neglect of job search plan & & $\begin{array}{l}324 \\
(5.4 \%)\end{array}$ & & & \\
\hline Repeated neglect of job search plan ${ }^{b}$ & & $\begin{array}{l}38 \\
(0.6 \%)\end{array}$ & & & \\
\hline Total & $\begin{array}{l}133 \\
(2.2 \%)\end{array}$ & $\begin{array}{l}5,733 \\
(95.1 \%)\end{array}$ & $\begin{array}{l}44 \\
(0.7 \%)\end{array}$ & $\begin{array}{l}117 \\
(1.9 \%)\end{array}$ & $\begin{array}{l}6,027 \\
(100 \%)\end{array}$ \\
\hline \multicolumn{6}{|l|}{ Labour market support (LMS) } \\
\hline Refusal of work & & $\begin{array}{l}4,130 \\
(18.5 \%)\end{array}$ & & & \\
\hline Refusal of work, fewer than five days & $\begin{array}{l}80 \\
(0.4 \%)\end{array}$ & & & & \\
\hline Refusal of ALMP ${ }^{a}$ & & $\begin{array}{l}6,657 \\
(29.8 \%)\end{array}$ & & $\begin{array}{l}8,367 \\
(37.5 \%)\end{array}$ & \\
\hline Repeated refusal of work or ALMP & & & $\begin{array}{l}722 \\
(3.2 \%)\end{array}$ & & \\
\hline Neglect of job search plan & & $\begin{array}{l}2,317 \\
(10.4 \%)\end{array}$ & & & \\
\hline Repeated neglect of job search plan & & & $\begin{array}{l}68 \\
(0.3 \%)\end{array}$ & & \\
\hline Total & $\begin{array}{l}80 \\
(0.4 \%)\end{array}$ & $\begin{array}{l}13,104 \\
(58.7 \%)\end{array}$ & $\begin{array}{l}790 \\
(3.5 \%)\end{array}$ & $\begin{array}{l}8,367 \\
(37.5 \%)\end{array}$ & $\begin{array}{l}22,341 \\
(100 \%)\end{array}$ \\
\hline All unemployed individuals & $\begin{array}{l}213 \\
(0.8 \%)\end{array}$ & $\begin{array}{l}18,837 \\
(66.4 \%)\end{array}$ & $\begin{array}{l}834 \\
(2.9 \%)\end{array}$ & $\begin{array}{l}8,484 \\
(29.9 \%)\end{array}$ & $\begin{array}{l}28,368 \\
(100 \%)\end{array}$ \\
\hline
\end{tabular}

Notes: ${ }^{\text {a }}$ The sanction for long-term unemployed individuals (duration of more than 500 days) is the exclusion of benefits until 150 days of work, education or labour market policy measures are performed. ${ }^{\mathrm{b}}$ The sanction for UI benefit recipients is 60 days. 


\section{Appendix C. The results for the exit rate to work without heterogeneity and with discrete heterogeneity}

\begin{tabular}{|c|c|c|c|c|}
\hline & $\begin{array}{r}\text { Earnings- } \\
\text { related (UI) }\end{array}$ & $\begin{array}{l}\text { Earnings- } \\
\text { related (UI) }\end{array}$ & $\begin{array}{l}\text { Labour market } \\
\text { support (LMS) }\end{array}$ & $\begin{array}{l}\text { Labour market } \\
\text { support (LMS) }\end{array}$ \\
\hline & I & II & III & IV \\
\hline & Without & With discrete & Without & With discrete \\
\hline & heterogeneity & heterogeneity & heterogeneity & heterogeneity \\
\hline & Coeff. (s. e.) & Coeff. (s. e.) & Coeff. (s. e.) & Coeff. (s. e.) \\
\hline \multicolumn{5}{|l|}{ Sanction } \\
\hline \multirow[t]{2}{*}{ Ongoing } & $0.16 * * *$ & $0.18 * * *$ & $0.56 * * *$ & $0.65 * * *$ \\
\hline & $(0.03)$ & (0.03) & $(0.01)$ & $(0.01)$ \\
\hline \multirow[t]{2}{*}{ Completed } & -0.02 & -0.01 & $0.24 * * *$ & $0.32 * * *$ \\
\hline & $(0.02)$ & $(0.02)$ & $(0.02)$ & (0.02) \\
\hline \multirow[t]{2}{*}{ Women } & $0.08 * * *$ & $0.08 * * *$ & $0.09 * * *$ & $0.16^{* * *}$ \\
\hline & $(0.01)$ & (0.01) & $(0.00)$ & $(0.00)$ \\
\hline \multirow[t]{2}{*}{ Non-Finn } & $-0.12 * * *$ & $-0.14 * * *$ & $-0.41 * * *$ & $-0.47 * * *$ \\
\hline & $(0.02)$ & $(0.02)$ & (0.01) & $(0.01)$ \\
\hline \multirow[t]{2}{*}{ Swedish-speaking } & 0.01 & $0.03 *$ & $0.09 * * *$ & $0.11 * * *$ \\
\hline & $(0.01)$ & $(0.02)$ & $(0.01)$ & (0.01) \\
\hline \multicolumn{5}{|l|}{ Age } \\
\hline \multirow[t]{2}{*}{$30-34$} & $-0.04 * * *$ & $-0.05 * * *$ & $-0.15 * * *$ & $-0.16 * * *$ \\
\hline & $(0.01)$ & $(0.01)$ & $(0.01)$ & $(0.01)$ \\
\hline \multirow[t]{2}{*}{$35-39$} & $-0.05 * * *$ & $-0.07 * * *$ & $-0.24 * * *$ & $-0.26 * * *$ \\
\hline & $(0.01)$ & $(0.01)$ & (0.01) & $(0.01)$ \\
\hline \multirow[t]{2}{*}{$40-44$} & $-0.04 * * *$ & $-0.07 * * *$ & $-0.29 * * *$ & $-0.33 * * *$ \\
\hline & $(0.01)$ & (0.01) & (0.01) & $(0.01)$ \\
\hline \multirow[t]{2}{*}{$45-49$} & $-0.05 * * *$ & $-0.06 * * *$ & $-0.32 * * *$ & $-0.36 * * *$ \\
\hline & 01) & $(0.01)$ & $(0.01)$ & $(0.01)$ \\
\hline \multicolumn{5}{|l|}{ Education } \\
\hline \multirow[t]{2}{*}{ Upper secondary level } & $.04 * * *$ & $0.04 * * *$ & $0.07 * * *$ & $0.11 * * *$ \\
\hline & $(0.01)$ & $(0.01)$ & $(0.00)$ & $(0.00)$ \\
\hline \multirow[t]{3}{*}{ Lowest-level tertiary } & 0.01 & 0.01 & $0.15^{* * *}$ & $0.20 * * *$ \\
\hline & $(0.01)$ & $(0.01)$ & $(0.01)$ & $(0.01)$ \\
\hline & $0.04 * * *$ & $0.06 * * *$ & $0.24 * * *$ & $0.35 * * *$ \\
\hline \multirow{3}{*}{ Regional unemployment } & $(0.01)$ & $(0.01)$ & $(0.01)$ & $(0.01)$ \\
\hline & -0.00 & -0.00 & $-0.01 * * *$ & $-0.02 * * *$ \\
\hline & $(0.00)$ & $(0.00)$ & $(0.00)$ & $(0.00)$ \\
\hline $\log ($ UI benefit level $)$ & $0.04 * * *$ & $0.02 * *$ & & \\
\hline \multirow{2}{*}{$U I_{0}$} & $(0.01)$ & $(0.01)$ & & \\
\hline & $0.21 * * *$ & $0.22 * * *$ & & \\
\hline & $(0.01)$ & $(0.01)$ & & \\
\hline \multirow[t]{2}{*}{$U I_{60}$} & $0.34 * * *$ & $0.37 * * *$ & & \\
\hline & $(0.01)$ & $(0.01)$ & & \\
\hline \multirow[t]{2}{*}{$U I_{120}$} & $0.26 * * *$ & $0.28 * * *$ & & \\
\hline & $(0.01)$ & $(0.01)$ & & \\
\hline \multirow[t]{3}{*}{ Member of UI fund } & & & $0.99 * * *$ & $1.24 * * *$ \\
\hline & & & $(0.00)$ & $(0.00)$ \\
\hline & & & & (continued) \\
\hline
\end{tabular}




\section{Appendix C. (continued)}

\begin{tabular}{|c|c|c|c|c|}
\hline & $\begin{array}{r}\text { Earnings- } \\
\text { related (UI) }\end{array}$ & $\begin{array}{r}\text { Earnings- } \\
\text { related (UI) }\end{array}$ & $\begin{array}{l}\text { Labour market } \\
\text { support (LMS) }\end{array}$ & $\begin{array}{l}\text { Labour marke } \\
\text { support (LMS) }\end{array}$ \\
\hline & I & II & III & IV \\
\hline & Without & With discrete & Without & With discrete \\
\hline & heterogeneity & heterogeneity & heterogeneity & heterogeneity \\
\hline & Coeff. (s. e.) & Coeff. (s. e.) & Coeff. (s. e.) & Coeff. (s. e.) \\
\hline \multicolumn{5}{|c|}{ Number of unemployment days, $0-1$} \\
\hline \multicolumn{5}{|l|}{ year ago } \\
\hline $0-49$ & $(0.01)$ & $\begin{array}{r}3.22 \text { ( } 2.01) \\
(0.01)\end{array}$ & $\begin{array}{r}0.06+100 \\
(0.00)\end{array}$ & $\begin{array}{r}0.05+101) \\
(0.01)\end{array}$ \\
\hline \multirow[t]{2}{*}{$50-99$} & $1.61 * * *$ & $1.74 * * *$ & $0.16^{* * *}$ & $0.11 * * *$ \\
\hline & $(0.01)$ & $(0.01)$ & $(0.01)$ & $(0.01)$ \\
\hline \multirow[t]{2}{*}{$100-149$} & $0.85 * * *$ & $0.93 * * *$ & 0.01 & 0.01 \\
\hline & $(0.01)$ & $(0.01)$ & $(0.01)$ & $(0.02)$ \\
\hline \multirow[t]{2}{*}{$150-199$} & $0.35 * * *$ & $0.40 * * *$ & $-0.13 * * *$ & $-0.11 * * *$ \\
\hline & $(0.01)$ & $(0.01)$ & $(0.02)$ & $(0.02)$ \\
\hline \multirow[t]{2}{*}{$200-249$} & $-0.04 * * *$ & -0.02 & $-0.23 * * *$ & $-0.18 * * *$ \\
\hline & $(0.01)$ & $(0.02)$ & $(0.02)$ & $(0.03)$ \\
\hline \multirow[t]{2}{*}{$250-299$} & $-0.33 * * *$ & $-0.35 * * *$ & $-0.20 * * *$ & $-0.16^{* * *}$ \\
\hline & $(0.02)$ & $(0.02)$ & $(0.04)$ & $(0.05)$ \\
\hline \multicolumn{5}{|c|}{ Number of unemployment days, $1-2$ years ago } \\
\hline \multirow[t]{2}{*}{$0-49$} & $3.28 * * *$ & $3.38 * * *$ & $0.36 * * *$ & $0.18 * * *$ \\
\hline & $(0.03)$ & $(0.04)$ & $(0.01)$ & $(0.01)$ \\
\hline \multirow[t]{2}{*}{$50-99$} & $2.29 * * *$ & $2.39 * * *$ & $0.30 * * *$ & $0.19 * * *$ \\
\hline & $(0.02)$ & $(0.02)$ & $(0.01)$ & $(0.01)$ \\
\hline \multirow[t]{2}{*}{$100-149$} & $1.66 * * *$ & $1.73 * * *$ & $0.17 * * *$ & $0.13 * * *$ \\
\hline & $(0.01)$ & $(0.02)$ & $(0.02)$ & $(0.02)$ \\
\hline \multirow[t]{2}{*}{$150-199$} & & $1.35^{* * *}$ & 0.02 & $0.03 *$ \\
\hline & $(0.01)$ & $(0.02)$ & $(0.02)$ & $(0.02)$ \\
\hline \multirow[t]{2}{*}{$200-249$} & $0.91 * * *$ & $0.97 * * *$ & $-0.07 * * *$ & -0.02 \\
\hline & $(0.01)$ & $(0.02)$ & $(0.02)$ & $(0.02)$ \\
\hline \multirow[b]{3}{*}{ Occupation dummies } & $0.60 * * *$ & $0.64 * * *$ & $-0.15 * * *$ & $-0.06 * *$ \\
\hline & $(0.02)$ & $(0.02)$ & $(0.02)$ & $(0.02)$ \\
\hline & yes & yes & yes & yes \\
\hline Place of residence & entre) & yes & yes & yes \\
\hline \multicolumn{5}{|c|}{ dummies es } \\
\hline Calendar time dummies & yes & & yes & yes \\
\hline Unobserved & no & yes & no & yes \\
\hline \multicolumn{5}{|l|}{ heterogeneity } \\
\hline \multirow[t]{2}{*}{$v_{u}$} & & $-1.20 * * *$ & & $-1.68 * * *$ \\
\hline & & $(0.01)$ & & $(0.01)$ \\
\hline \multirow[t]{2}{*}{$p_{1}$} & & $0.13 * * *$ & & $0.52 * * *$ \\
\hline & & $(0.00)$ & & $(0.00)$ \\
\hline \multirow[t]{2}{*}{$p_{2}$} & & $0.88 * * *$ & & $0.48 * * *$ \\
\hline & & $(0.00)$ & & $(0.00)$ \\
\hline Log likelihood & $-1,616,374$ & $-1,611,897$ & $-1,871,627$ & $-1,848,490$ \\
\hline Number of individuals & 198,341 & 198,341 & 266,209 & 266,209 \\
\hline
\end{tabular}

Notes: To conserve space, estimates for the baseline hazard are not presented. The reference groups are as follows: 25-29 years old (age), primary level (education),300-365 (number of unemployment days, 0-1 year ago, 300-365 (number of unemployment days, 1-2 years ago), unclassified (occupation), Uusimaa (place of residence) and 2005q1 (calendar time). ***, ** and * indicate significance at the 1\%, 5\% and $10 \%$ levels, respectively. 
Appendix D. Results for the timing-of-events model with endogenous right censoring, earnings-related (UI) benefit receivers

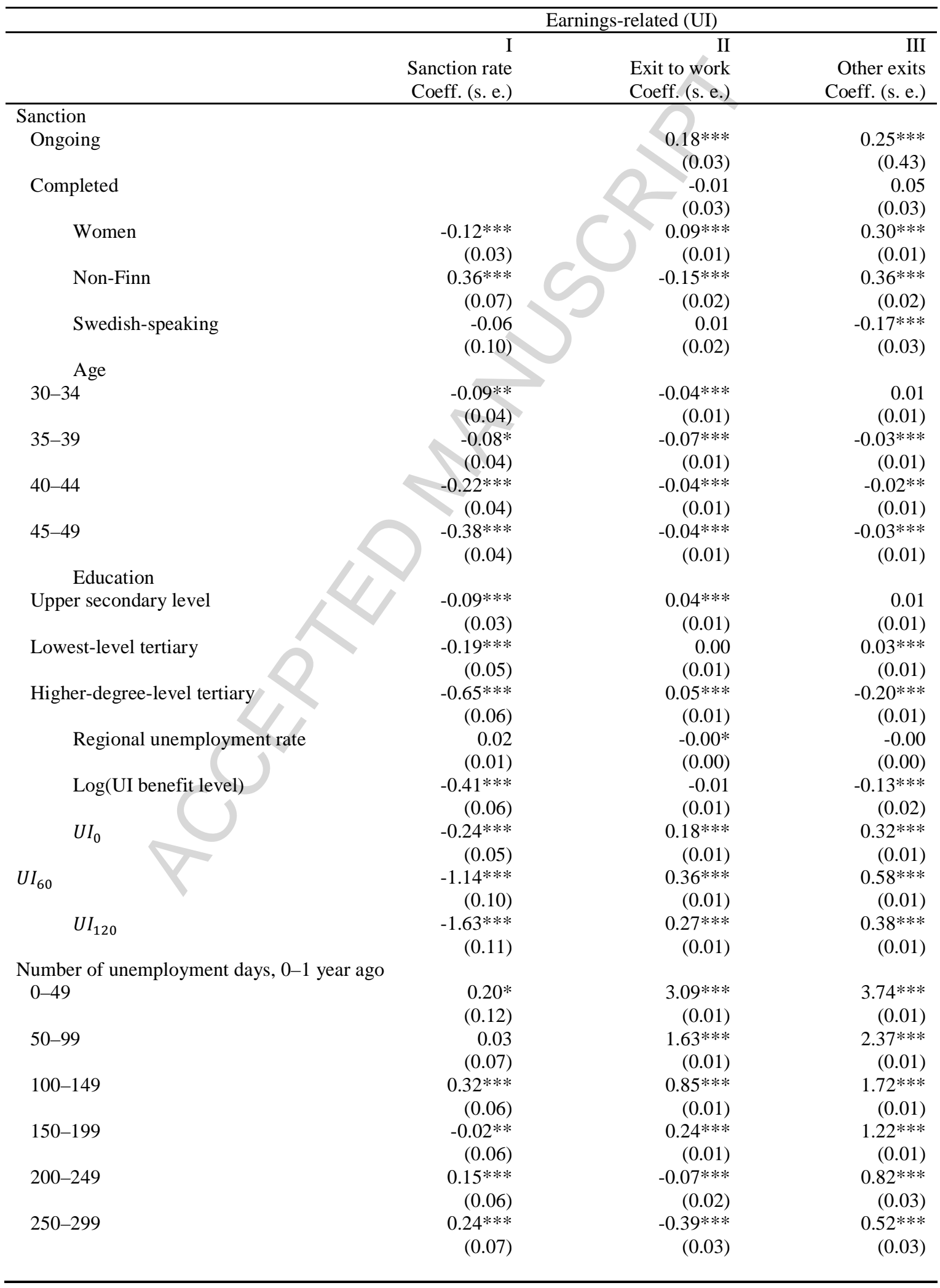




\section{Appendix D. (continued)}

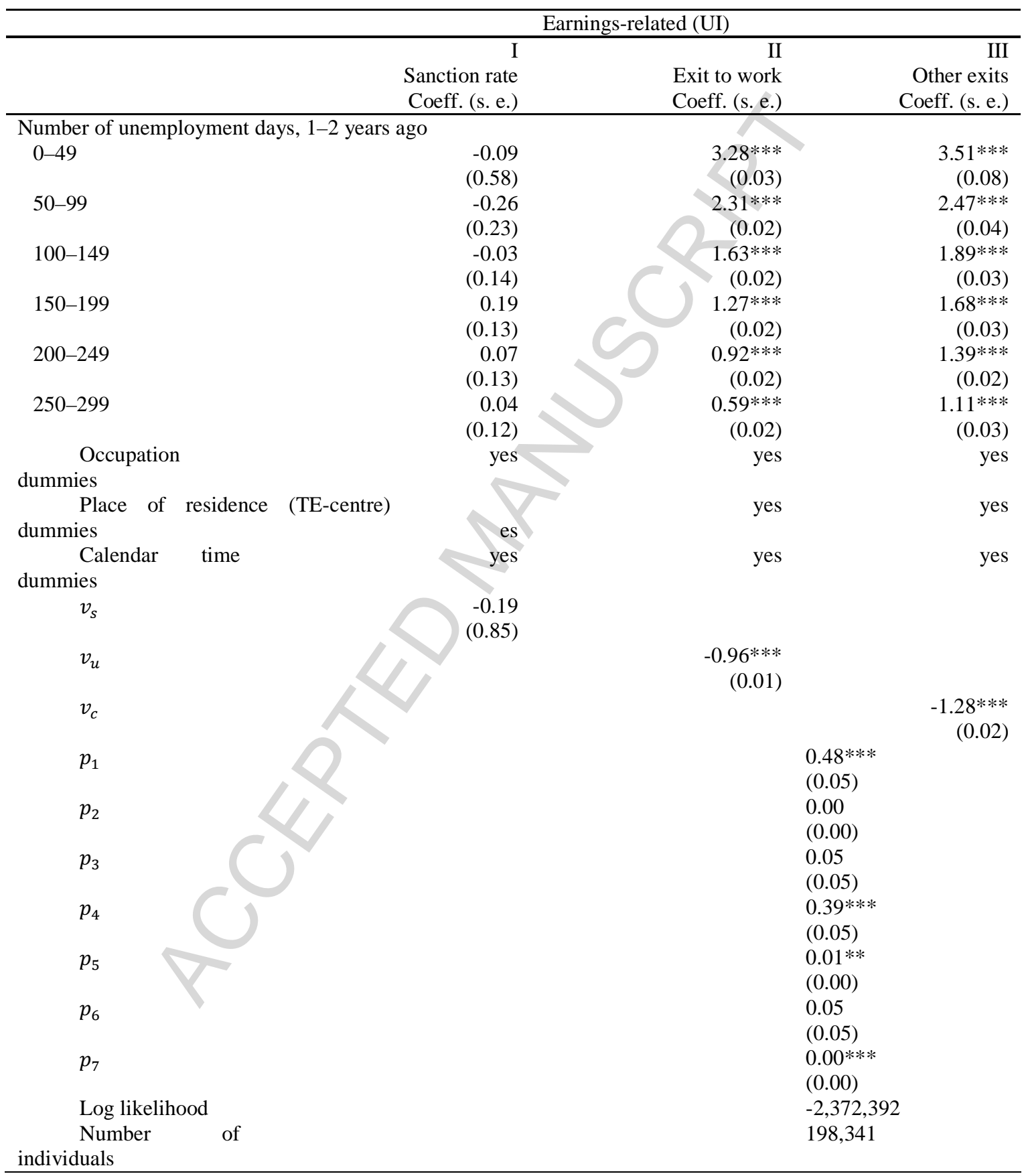

Notes: 'Other exits' include exit from unemployment to an ALMP measure and to outside of the labour force. To conserve space, estimates for the baseline hazard are not presented. The reference groups are as follows: 25-29 years old (age), primary level (education),300-365 (number of unemployment days, 0-1 year ago, 300-365 (number of unemployment days, 1-2 years ago), unclassified (occupation), Uusimaa (place of residence) and $2005 \mathrm{q} 1$ (calendar time). ***, ** and * indicate significance at the $0.1 \%, 5 \%$ and $10 \%$ levels, respectively. 


\section{Appendix E. Results for the timing-of-events model with endogenous right censoring, labour market support (LMS) receivers}

\begin{tabular}{|c|c|c|c|}
\hline & & t support (LMs & \\
\hline & $\mathrm{I}$ & II & III \\
\hline & Sanction rate & Exit to work & Other exits \\
\hline & Coeff. (s. e.) & Coeff. (s. e.) & Coeff. (s. e.) \\
\hline Sanction & & & \\
\hline Ongoing & & & $0.21 * * *$ \\
\hline & & & $(0.02)$ \\
\hline Completed & & $0.31 * * *$ & $0.10 * * *$ \\
\hline & & $(0.02)$ & $(0.02)$ \\
\hline Women & $-0.15 * * *$ & $0.15 * * *$ & $0.36 * * *$ \\
\hline & $(0.02)$ & $(0.01)$ & $(0.01)$ \\
\hline Non-Finn & $-0.08 * * *$ & $-0.52 * * *$ & $0.97 * * *$ \\
\hline & $(0.02)$ & $(0.01)$ & $(0.01)$ \\
\hline Swedish-speaking & $-0.16 * * *$ & $0.11 * * *$ & $-0.20 * * *$ \\
\hline & $(0.02)$ & $(0.02)$ & $(0.02)$ \\
\hline Age & & & \\
\hline $30-34$ & 0.02 & $-0.16^{* * *}$ & 0.00 \\
\hline & $(0.02)$ & $(0.01)$ & $(0.01)$ \\
\hline $35-39$ & -0.02 & $-0.26 * * *$ & $-0.04 * * *$ \\
\hline & $(0.02)$ & $(0.01)$ & $(0.01)$ \\
\hline $40-44$ & $-0.08 * * *$ & $-0.32 * * *$ & $-0.06 * * *$ \\
\hline & $(0.02)$ & $(0.01)$ & $(0.01)$ \\
\hline $45-49$ & $-0.14 * * *$ & $-0.36 * * *$ & $-0.08 * * *$ \\
\hline & $(0.02)$ & $(0.01)$ & $(0.01)$ \\
\hline Education & & & \\
\hline Upper secondary level & $-0.12 * * *$ & $0.11 * * *$ & $0.04 * * *$ \\
\hline & $(0.02)$ & $(0.01)$ & $(0.01)$ \\
\hline Lowest-level tertiary & $-0.11 * * *$ & $0.20 * * *$ & $0.06 * * *$ \\
\hline & $(0.03)$ & $(0.01)$ & $(0.01)$ \\
\hline Higher-degree-level tertiary & $-0.64 * * *$ & $0.34 * * *$ & 0.00 \\
\hline & $(0.03)$ & $(0.01)$ & $(0.01)$ \\
\hline Regional unemployment rate & $-0.04 * * *$ & $-0.01 * * *$ & $-0.02 * * *$ \\
\hline & $(0.01)$ & $(0.00)$ & $(0.00)$ \\
\hline Member of UI fund & $-0.49 * * *$ & $1.24 * * *$ & $-0.03 * * *$ \\
\hline & $(0.02)$ & $(0.00)$ & $(0.01)$ \\
\hline Number of unemployment days, $0-1$ & & & \\
\hline $0-49$ & $-0.04 *$ & $0.04 * * *$ & $0.06 * * *$ \\
\hline & $(0.02)$ & $(0.01)$ & $(0.01)$ \\
\hline $50-99$ & $-0.11 * *$ & $0.13 * * *$ & $0.13 * * *$ \\
\hline & $(0.05)$ & $(0.01)$ & $(0.01)$ \\
\hline $100-149$ & $-0.11 *$ & 0.02 & $0.11 * * *$ \\
\hline & $(0.06)$ & $(0.02)$ & $(0.02)$ \\
\hline $150-199$ & 0.02 & $-0.11 * * *$ & $0.06 * * *$ \\
\hline & $(0.06)$ & $(0.02)$ & $(0.02)$ \\
\hline $200-249$ & 0.11 & $-0.19 * * *$ & $0.05 *$ \\
\hline & $(0.08)$ & $(0.03)$ & $(0.03)$ \\
\hline $250-299$ & -0.03 & $-0.21 * * *$ & $0.08 * *$ \\
\hline & $(0.12)$ & $(0.05)$ & $(0.04)$ \\
\hline
\end{tabular}




\section{Appendix E. (continued)}

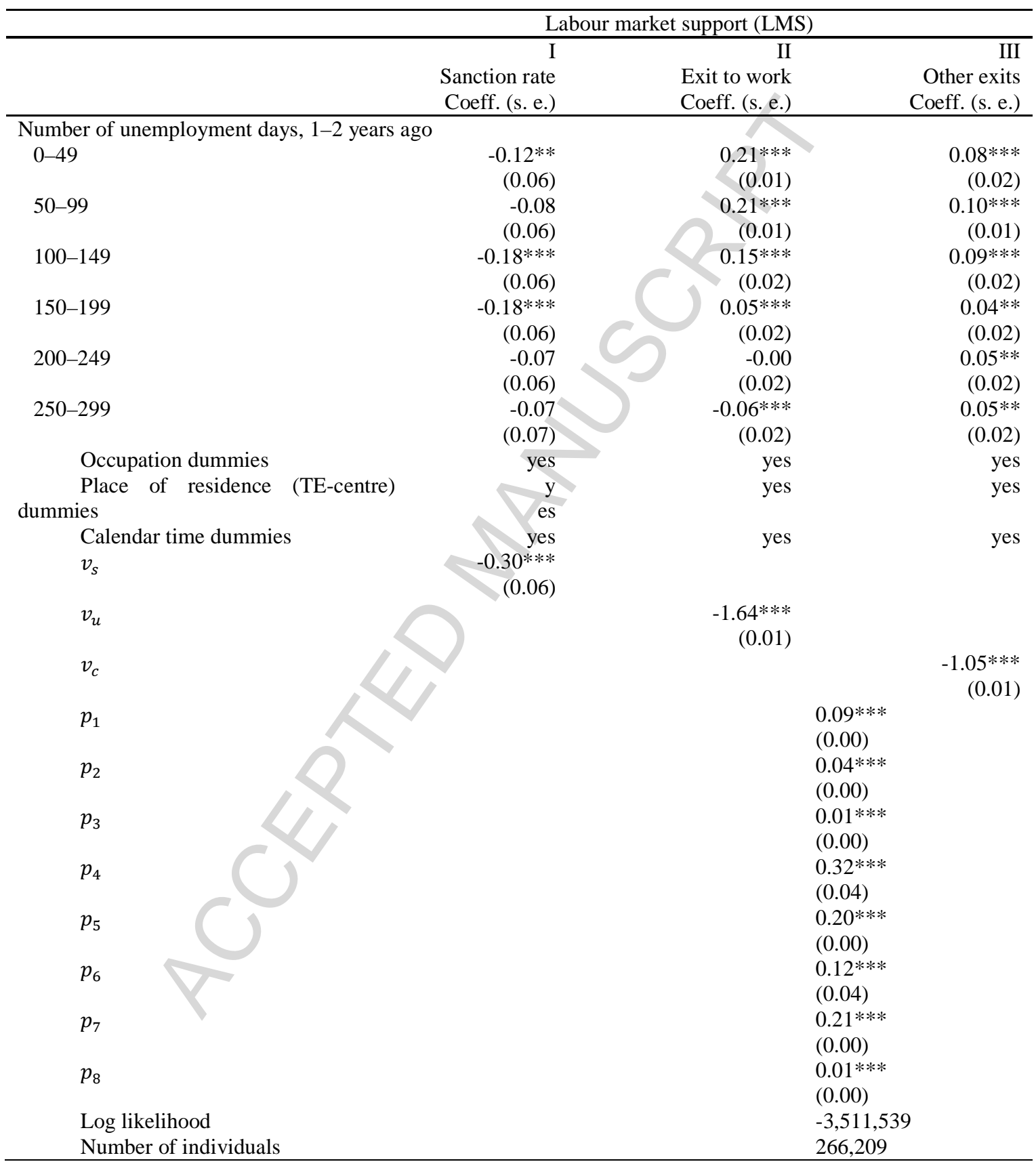

Notes: 'Other exits' include exit from unemployment to an ALMP measure and to outside of the labour force. To conserve space, estimates for the baseline hazard are not presented. The reference groups are as follows: 25-29 years old (age), primary level (education),300-365 (number of unemployment days, 0-1 year ago, 300-365 (number of unemployment days, 1-2 years ago), unclassified (occupation), Uusimaa (place of residence) and $2005 q 1$ (calendar time). $* * *, * *$ and $*$ indicate significance at the $0.1 \%, 5 \%$ and $10 \%$ levels, respectively. 


\section{References}

Abbring, J. and Van den Berg, G. (2003). The nonparametric identification of treatment effects in duration models. Econometrica71, 1491-1517.

Abbring, J., Van den Berg, G. and Van Ours, J. (2005). The effect of unemployment insurance sanctions on the transition rate from unemployment to employment. The Economic Journal 115, 602-630.

Anderson, P. and Meyer, B. (1997). Unemployment insurance takeup rates and the after-tax value of benefits. Quarterly Journal of Economics 112, 913-937.

Arni, P., Lalive, R. and Van Ours, J. (2012). How effective are unemployment benefit sanctions? Looking beyond unemployment exit. Journal of Applied Econometrics 28, 1153-1178.

Blasco, S. and Fontaine, F. (2012). A structural model of the unemployment insurance takeup. Working paper, manuscript.

Boockmann, B., Thomsen, S.L. and Walter, T. (2009). Intensifying the use of benefit sanctions: an effective tool to shorten welfare receipt and speed up transitions to employment? IZA Discussion Papers 4580. IZA, Bonn.

Boone, J., Sadrieh, A. and van Ours, J. (2009). Experiments on unemployment benefit sanctions and job search behaviour. European Economic Review 53, 937-951.

Boone, J. and Van Ours, J. (2006). Modelling financial incentives to get the unemployed back to work. Journal of Institutional and Theoretical Economics 162, 227-252.

Brinch, C.N. (2007). Nonparametric identification of the mixed hazards model with timevarying covariates. Econometric Theory 23, 349-354.

Card, D., Chetty, R. and Weber, A. (2007). The spike at benefit exhaustion: leaving unemployment system or starting a new job? The American Economic Review 97, 113118. 
Douglas, I., Kerminen, P., Meling, T. and Peura, J. (2011). Työttömyysturvan menettäminen työvoimapoliittisesti moitittavan menettelyn takia (Benefit sanctions). TEM Analyses 31/2011. Ministry of Employment and the Economy, Helsinki.

Gaure, S., Røed, K. and Zhang, T. (2007). Time and causality: A Monte Carlo assessment of the timing-of-events approach. Journal of Econometrics 141, 1159-1195.

Gonzalo, M.R. and Saarela, J. (2000). Gender differences in exit rates from unemployment: evidence from a local Finnish labour market. Finnish Economic Papers 13, 129-139.

Gray, D. (2003). National versus regional financing and management of unemployment and related benefits: the case of Candied Social, Employment and Migration Working Papers 14. OECD, Paris.

Grubb, D. (2000). Eligibility criteria for unemployment benefits. OECD Economic Studies 31. OECD, Paris.

Ham, J. and Rea, S. (1987). Unemployment insurance and male unemployment duration in Canada. Journal of Labor Economics 5, 325-353.

Hannikainen-Ingman, K., Hiilamo, H., Honkanen, P., Kuivalainen, S. and Moisio, P. (2012). Perus- ja vähimmäisturvan yleisyys ja päällekkäisyys 2000-2009 (Prevalence and overlap of social benefits in 2000-2009). Kelan nettityöpapereita 33. Available (in Finnish) at<http://hdl.handle.net/10138/29197> (accessed 15 March 2016).

Hasenfeld, Y., Ghose, T. and Larson, K. (2004). The logic of sanctioning welfare recipients: an empirical assessment. Social Service Review 78, 304-319.

Hillmann, K and Hohenleitner, I. (2012). Impact of benefit sanctions on unemployment outflow - evidence from German survey data. HWWI Research Paper 129. Hamburg Institute of International Economics (HWWI), Hamburg.

Kroft, K. (2008). Takeup, Social multipliers and optimal social insurance. Journal of Public Economics 93, 722-737. 
Krueger, A. and Mueller, A. (2010). Job search and unemployment insurance: new evidence from time use data. Journal of Public Economics 94, 298-307.

Kyyrä, T. (1999). Post-unemployment wages and economic incentives to exit from unemployment. VATT-Research Reports 56. VATT, Helsinki.

Lalive, R., Zweimuller, J. and van Ours, J. (2005). The effect of benefit sanctions on the duration of unemployment. Journal of the European Association 3, 1386-1417.

Lilja, R. (1993). Unemployment benefit system and unemployment duration in Finland. Finnish Economic Papers 6, 25-37.

Meyer, B. (1990). Unemployment insurance and unemployment spells. Econometrica 58, 757-782.

Moffitt, R. and Nicholson, W. (1982). The effect of unemployment insurance on unemployment: the case of federal supplement benefits. The Review of Economics and Statistics 64, 1-11.

Mortensen, D. (1977). Unemployment insurance and job search decisions. Industrial and Labor Relations Review30, 505-517.

Müller, K.-U. and Steiner, V. (2008). Imposed benefit sanctions and the unemployment-toemployment transition: the German experience. IZA Discussion Papers 3483. IZA, Bonn.

Ollikainen, V. (2003). The determinants of unemployment duration by gender in Finland. VATT Discussion Papers 316. VATT, Helsinki.

Røed, K. and Westlie, L. (2012). Unemployment insurance in welfare states: the impacts of soft duration constraints. Journal of the European Economic Association 10, 518-554.

Svarer, M. (2011). The effect of sanctions on exit from unemployment: evidence from Denmark. Economica 78, 751-778. 
Van den Berg, G. (2001). Duration models: specification, identification and multiple durations. In: Heckman JJ, Leamer E (Eds), Handbook of Econometrics, vol.5. Elsevier: Amsterdam, p. 3381-3460.

Van den Berg, G., van der Klaauw, B. and van Ours, J. (2004). Punitive sanctions and the transition rate from welfare to work. Journal of Labor Economics 22, 211-241.

Van den Berg, G. and Vikström, J. (2014). Monitoring job offer decisions, punishments, exit to work, and job quality. Scandinavian Journal of Economics 116, 284-334.

Virjo, I., Aho, S. and Koponen, H. (2006). Passivoiko työttömyysturva? (Does unemployment security make people more passive?). Studies in Labour Policy 303. Ministry of Employment and the Economy, Helsinki. 


\section{HIGHLIGHTS}

- We examine the effect of benefit sanctions on the exit rate from unemployment using the timing-of-events approach.

- The effect of sanctions differs according to the benefits received.

- Sanctions increase the exit rate from unemployment to work among flat-rate labour market support receivers.

- $\quad$ Sanctions increase the exit rate from unemployment to outside the labour force among earnings-related benefit receivers. 